\title{
A review of alpha-glucosidase inhibitors from plants as potential candidates for the treatment of type- 2 diabetes
}

\author{
Amina M. Dirir • Marianne Daou • Ahmed F. Yousef $・$ Lina F. Yousef $\mathbb{C}$
}
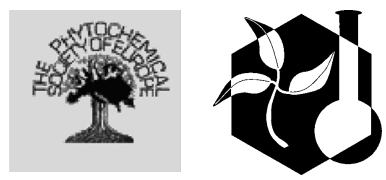

Received: 15 October 2020/Accepted: 27 July 2021 / Published online: 16 August 2021

(C) The Author(s), under exclusive licence to Springer Nature B.V. 2021

\begin{abstract}
Diabetes mellitus is a multifactorial global health disorder that is rising at an alarming rate. Cardiovascular diseases, kidney damage and neuropathy are the main cause of high mortality rates among individuals with diabetes. One effective therapeutic approach for controlling hyperglycemia associated with type-2 diabetes is to target alpha-amylase and alpha-glucosidase, enzymes that catalyzes starch hydrolysis in the intestine. At present, approved inhibitors for these enzymes are restricted to acarbose, miglitol and voglibose. Although these inhibitors retard glucose absorption, undesirable gastrointestinal side effects impede their application. Therefore, research efforts continue to seek novel inhibitors with improved efficacy and minimal side effects. Natural products of plant origin have been a valuable source of therapeutic agents with lesser toxicity and side effects. The anti-diabetic potential through alpha-glucosidase inhibition of plant-derived
\end{abstract}

Supplementary Information The online version contains supplementary material available at https://doi.org/10.1007/ s11101-021-09773-1.

A. M. Dirir · M. Daou · A. F. Yousef · L. F. Yousef ( $\square)$ Department of Chemistry, Khalifa University, Abu Dhabi, UAE

e-mail: lina.yousef@ku.ac.ae

A. F. Yousef

Center for Membranes and Advances Water Technology,

Khalifa University, Abu Dhabi, UAE molecules are summarized in this review. Eight molecules (Taxumariene F, Akebonoic acid, Morusin, Rhaponticin, Procyanidin A2, Alaternin, Mulberrofuran $\mathrm{K}$ and Psoralidin) were selected as promising drug candidates and their pharmacokinetic properties and toxicity were discussed where available.

Keywords Alpha-glucosidase - Diabetes · Tannins · Stilbenes $\cdot$ Triterpenoids $\cdot \mathrm{IC}_{50}$

$\begin{array}{ll}\text { Abbreviations } \\ \text { A } \beta & \text { Amyloid beta } \\ \text { AchE } & \text { Acetylcholinesterase } \\ \text { BACE1 } & \begin{array}{l}\text { B-Site amyloid precursor protein cleaving } \\ \text { enzyme 1 }\end{array} \\ \text { Bax } & \text { BCL2-associated X } \\ \text { BchE } & \text { Butyrylcholinesterase } \\ \text { Bcl-2 } & \text { B-cell lymphoma 2 } \\ \text { COX-2 } & \text { Cyclooxygenase-2 } \\ \text { CYP } & \text { Cytochrome P450 } \\ \text { ERK } & \text { Extracellular-regulated kinases } \\ \text { FAS } & \text { Fatty acid synthase } \\ \text { GSH } & \text { Glutathione } \\ \text { HMAO } & \text { Human monoamine oxidase } \\ \text { HO-1 } & \text { Heme oxygenase-1 } \\ \text { IL-1B } & \text { Interleukin 1 beta } \\ \text { iNOS } & \text { Inducible nitric oxide synthase } \\ \text { JNK } & \text { C-Jun N-terminal kinase } \\ \text { LDH } & \text { Lactate dehydrogenase } \\ \text { LDL } & \text { Low-density lipoprotein }\end{array}$




\begin{tabular}{|c|c|}
\hline LOX & Lipoxygenase \\
\hline LPS & Lipopolysaccharide \\
\hline МPTP & $\begin{array}{l}\text { 1-Methyl-4-phenyl-1,2,3,6- } \\
\text { tetrahydropyridine }\end{array}$ \\
\hline $\mathrm{NF}-\kappa \mathrm{B}$ & Nuclear factor- $\kappa \mathrm{B}$ \\
\hline NO & Nitric oxide \\
\hline NQO1 & $\mathrm{NAD}(\mathrm{P}) \mathrm{H}$ quinone dehydrogenase \\
\hline Nrf2 & Nuclear factor erythroid 2-related factor 2 \\
\hline p38 & P38 MAP kinase \\
\hline PSE & Peanut skin extract \\
\hline $\mathrm{PGE}_{2}$ & Prostaglandin $\mathrm{E}_{2}$ \\
\hline PTP1B & Protein tyrosine phosphatase $1 \mathrm{~B}$ \\
\hline $\begin{array}{l}\text { SARS- } \\
\text { CoV }\end{array}$ & $\begin{array}{l}\text { Severe acute respiratory syndrome } \\
\text { coronavirus }\end{array}$ \\
\hline ROS & Reactive oxygen species \\
\hline$t$-BOOH & Tert-Butyl hydroperoxide \\
\hline TNF- $\alpha$ & Tumor necrosis factor alpha \\
\hline UGT & UDP-glucuronosyltransferase \\
\hline
\end{tabular}

\section{Introduction}

Diabetes mellitus (DM) is an endocrine metabolic disorder characterized by abnormal levels of glucose in the blood stream (Alrefai et al. 2002). Owing to the unhealthy lifestyle activities, the global prevalence of diabetes is rising and the number of diabetes cases is projected to reach 578 million cases by the year 2030 (Saeedi et al. 2019). Insulin, a peptide hormone produced by the pancreatic $\beta$-cells, plays a key role in the regulation of blood glucose levels and energy metabolism. It is essential for a myriad of cellular functions including glucose uptake and transport, glycogen synthesis, fatty acid synthesis and protein synthesis. Insufficient production of insulin or insulin resistance impair the normal glucose homeostasis, which eventually lead to hyperglycemia (Wilcox 2005). Chronic hyperglycemia can result in serious long-term complications including nerve damage, cardiovascular disease and kidney failure (Tripathi and Srivastava 2006).

Diabetes can be classified into two broad categories; type 1 and type 2 diabetes. Type 1 diabetes, also known as insulin-dependent diabetes, is one of the most common metabolic disorders occurring in childhood (Atkinson et al. 2014). The pathogenesis of type 1 diabetes involves $\mathrm{T}$-cell mediated autoimmune destruction of the pancreatic beta-cells that produce insulin. Subsequently, this leads to a deficiency of insulin secretion in the body, resulting in the onset of the disease (Simmons and Michels 2015). On the other hand, type 2 diabetes is the most prevalent form of diabetes, comprising 90-95\% of all the cases (Fan 2017). This form of diabetes is caused by a combination of insulin resistance and impaired insulin secretion (Watada and Tamura 2017). The insensitivity of the target tissues to insulin can be manifested by the failure of glucose uptake in the skeletal muscle cells, and also due to the increased formation of glucose in the liver (Ormazabal et al. 2018). The major risk factors associated with the onset and the aggravation of type 2 diabetes include obesity, physical inactivity and vitamin D deficiency (Wu et al. 2014b).

Until now, there is no definitive treatment that can effectively modulate the metabolic dysfunction associated with diabetes. In this vein, several pharmacological approaches have been used to control hyperglycemia which is the major cause of diabetes complications. Treatments often include insulin injection for patients of type I diabetes or oral medications combined with lifestyle changes for the management of type 2 diabetes (Aziz 2012). The therapeutic intervention using non-insulin medications is based on reversing the pathophysiological abnormalities that contribute to hyperglycemia (Chatterjee and Davies 2015). In other words, such drugs hinder glucose absorption, suppress hepatic gluconeogenesis and inhibit renal reabsorption of glucose. Examples of common anti-diabetic drugs that promote the aforementioned effects include alpha-glucosidase inhibitors, metformin and sodium-glucose co-transporter-2 (SGLT-2) inhibitors (Bhowmick and Banu 2017). However, despite their prominent role in attenuating blood glucose levels, the adverse effects associated with these drugs are inevitable.

Alpha-glucosidase inhibitors stand out as a noninvasive treatment associated with mild, short-lived and dose-dependent gastrointestinal (GI) side effects including diarrhea, abdominal pain and flatulence (Hedrington and Davis 2019). By temporarily delaying the intestinal absorption of carbohydrates and thereby suppressing the elevation of postprandial blood glucose levels (Bischoff 1995), they present a convenient method in regulating type 2 diabetes which is directly linked to dietary habits. Currently, only three alpha-glucosidase inhibitors are utilized in clinical practice: acarbose, miglitol and voglibose 
<smiles>C[C@H]1O[C@H](O[C@@H]2[C@@H](CO)O[C@H](O[C@H]3[C@@H](CO)OC(O)[C@H](O)[C@H]3O)[C@H](O)[C@H]2O)[C@H](O)[C@@H](O)[C@H]1N[C@H]1C=C(CO)[C@@H](O)[C@H](O)[C@H]1O</smiles>

\section{Acarbose}

Fig. 1 Acarbose, miglitol and voglibose structures

(Fig. 1) and therefore research efforts seeking novel inhibitors with improved efficacy are increasing.

In recent decades, there has been a growing interest in the use of natural products as therapeutic compounds especially in the prevention and treatment of type 2 diabetes. Medicinal plants and traditional treatments were used throughout history as a remedy for all sorts of medical disorders including diabetes. Examples exceed herbal infusions and supplements to include approved drugs such as metformin, an antidiabetic drug originally isolated from the herbal plant Galega officinalis (Modak et al. 2007). This review provides an overview of 290 bioactive molecules from plant origin exhibiting alpha-glucosidase inhibition and it highlights the most promising drug candidates for managing type 2 diabetes through the inhibition of alpha-glucosidase enzyme.

\section{Search methodology}

Several studies isolated and characterized plant molecules that possess alpha-glucosidase inhibitory activity, and the topic was also reviewed by Yin et al. (2014) and Ghani (2015). Santos et al. (2018) reviewed the alpha-glucosidase inhibitory activity of more than 280 natural and synthetic plant-derived xanthones and highlighted the importance of these molecules in the development of anti-diabetic agents. In the current review, published work related to alphaglucosidase inhibitors of plant origin between the years 2015-2020 were collected using various electronic databases including PubMed, Scopus and Science Direct. The search terms used to collect the relevant papers involved a combination of "alphaglucosidase" with either "plant extracts" or with each of the chemical classes and subclasses presented in this review. Those studies that examined the alphaglucosidase inhibitory activities of synthetic and nonplant derived compounds (e.g. microorganisms) were excluded from the study. This review primarily discussed the in vitro alpha-glucosidase inhibitory activities of different plant extracts and specific molecules along with their biological activities, pharmacokinetic properties and toxicity. The search resulted in identifying 290 chemically diverse molecules exhibiting in vitro alpha-glucosidase inhibition. MarvinSketch software (version 20.15, ChemAxon, Budapest, Hungary) was used to draw the chemical structures of the reported bioactive compounds. Eight molecules were identified as promising candidates for future research on type 2-diabetes drug discovery. The 
selection was based on the following criteria: (1) the inhibitory efficiency compared to the positive controls, and (2) the variability in the chemical structure and plant origin. Selected compounds were further discussed with respect to other bioactivities of pharmaceutical importance, pharmacokinetic properties and toxicity profiles.

\section{Alpha-glucosidase: biological role and available inhibitors}

In the gastrointestinal tract, complex carbohydrates are digested by multiple breakdown reactions into monosaccharides which are absorbed in the small intestine. The digestion process begins with the secretion of amylases (EC 3.2.1.1) produced mainly by the pancreatic and salivary glands and catalyze the hydrolysis of starch into shorter polysaccharides (Mandel and Breslin 2012). The acidic environment of the stomach inhibits the enzymatic activity of the salivary amylase, which will hinder further breakdown of starch. Upon entry into the small intestine, partially hydrolyzed starch is further converted by the pancreatic amylases which targets the $\alpha-1,4$ bonds of the carbohydrate releasing dextrins (des Gachons and Breslin 2016). The final step in carbohydrates metabolism is mediated by alpha-glucosidases (EC 3.2.1.20) in the brush border of the enterocytes. The enzymes contain duplicated glycoside hydrolases (GH31) domains and they catalyze the hydrolysis of $\alpha$-glucosidic linkages of disaccharides and oligosaccharides (Jongkees and Withers 2014; Lombard et al. 2014). Reports have shown that alpha-glucosidase was 1.5 -fold overexpressed in noninsulin-dependent diabetes patients contributing to the increase in postprandial glucose levels (Dyer et al. 2002).

Polysaccharides and monosaccharides resulting from the action of alpha-amylase and alpha-glucosidase are absorbed at different rates by the body with monosaccharide units being absorbed more quickly. The inhibition of alpha-amylase and alpha-glucosidase activity can therefore retard glucose liberation from complex carbohydrates modulating the onset of postprandial hyperglycemia, thereby rendering it an ideal target for the management of type 2 diabetes. Alpha-amylase inhibitors are mainly present in plants and the most studied molecules are glycoproteins isolated from kidney beans (Phase 2 ( (reviewed in Barrett and Udani 2011). The most commonly prescribed alpha-glucosidase inhibitor is acarbose and it is a pseudo-carbohydrate isolated from actinomycetes (Luo et al. 2001). Other available inhibitors include, voglibose (from microbial origin) and miglitol (derived synthetically from 1-deoxynojirimycin) (Tan et al. 2018). The structural resemblance of these drugs with carbohydrates promote their attachment to the binding site of alpha-glucosidase enzyme. A recent in silico study found that these inhibitors interact with different residues of the enzyme including Phe178, Phe303, His280, His351, Arg315, Arg442 and Tyr158 (Ernawati et al. 2018). Acarbose, a pseudo-tetrasaccharide consisting of a valienol moiety linked via nitrogen to isomaltotriose. This molecule has a $10^{4}$ to $10^{5}$ times higher affinity for alpha-glucosidases compared to natural oligosaccharides and competitively inhibits this enzyme (Rosak and Mertes 2012). The binding affinity of acarbose to the enzyme is much higher than the normal sugar substrates due to hydrogen bond formation between ASP 568 and the hydrogen atom of the amine group (Abuelizz et al. 2019).

\section{Detection methods of alpha-glucosidase inhibition}

Several classical and new methods have been developed for the detection of alpha-glucosidase inhibition by natural and synthetic compounds. The colorimetric-based quantitative method is among the most common and practical approaches that has been utilized for the verification of the inhibitory role of different compounds against alpha-glucosidase enzyme. This method is based on the measurement of the quantity of $p$-nitrophenol (pNP) released when $p$-nitrophenyl- $\alpha$-D-glucopyranoside (pNPG) is hydrolyzed by alpha-glucosidase enzyme. This is followed by measuring spectrophotomerically the absorbance of the formed product which is characterized by a yellow color at $400 \mathrm{~nm}$ (Zhang et al. 2019). Another assay commonly used for the detection of alphaglucosidase activity is the colorimetric/fluorometric glucose oxidase assay which allows the detection and quantification of glucose released in the reaction.

We focused our review on studies that utilized the colorimetric spectrophotometric method to evaluate the alpha-glucosidase inhibitory activity of the isolated compounds. The majority of studies in this 
review assessed bioactivity of molecules using alphaglucosidase enzyme isolated from yeast and used pNPG as a substrate. Additionally, different reference compounds have been utilized in the evaluation of the alpha-glucosidase inhibitory activity of the various plant-derived compounds including acarbose, quercetin and 1-deoxynojirimycin. Although acarbose was the most commonly used positive standard, the reported $\mathrm{IC}_{50}$ values for this inhibitor varied widely and fell in the range of 0.0013-1998.79 $\mu \mathrm{M}$ (Tables 1 and 2 , online resource 1 ). The great variability in the obtained $\mathrm{IC}_{50}$ values for acarbose can be attributed to the different experimental conditions employed such as the enzyme source, the enzyme and substrate concentrations and the incubation times and temperatures. One consequence to that is the difficulty in interpreting results obtained from seperate papers and comparing bioactivities. The effect of the different experimental conditions and the various enzymes used on the sensitivity of the assay need to be assessed leading to a standardization of the protocol used.

\section{Crude plant extracts as a source of alpha- glucosidase inhibitors}

The potential role of herbal plants in the inhibition of alpha-glucosidase activity has been examined by different studies (Table 1). Among the plants studied in the papers that were included in this review, Chrysophyllum cainito and Ensete superbum extracts had the most remarkable inhibitory activities with $\mathrm{IC}_{50}$ values of $0.0012 \mathrm{mg} / \mathrm{mL}$ and $0.0018 \mathrm{mg} / \mathrm{mL}$, respectively compared to $0.198 \mathrm{mg} / \mathrm{mL}$ and $0.1215 \mathrm{mg} / \mathrm{mL}$ for acarbose (Doan et al. 2018; Habtemariam and Varghese 2017). Both plants are characterized by the presence of medicinally valuable phytochemicals including proanthocyanidin, gallic acid, rutin, quercetrin, $\beta$-amyrin and lupeol (Sayed et al. 2019; Sethiya et al. 2019). However, the active phytochemicals responsible for the observed alpha-glucosidase inhibitory activity are still to be identified. The oral administration of Chrysophyllum caimito at a dose of $75 \mathrm{mg} / \mathrm{kg}$ of body weight was found to significantly decrease sugar blood level in diabetic rats (Arrijal et al. 2018). Safety investigation have shown that the ingestion of leaves was safe and did not cause changes in the weight of the studied animals (Shailajan and Gurjar 2014). Similarly, Ensete superbum has been reported to cause no death and no signs of acute toxicity at doses of $2000 \mathrm{mg} / \mathrm{kg}$ (Ganesan and Natesan 2017). Those preliminary investigations support the potential use of this plant as anti-diabetic agent.

The nature of the extraction solvent used in the recovery of the plant constituents affected the measured inhibitory activities by different extracts. The similarity between the polarity of the solvent and the plant constituents is crucial for dissolving phytomolecules of interest (Altemimi et al. 2017). For example, ethanol used to extract polar molecules, while petroleum ether is appropriate for the extraction of non-polar compounds (Snehlata et al. 2018). For instance, the ethanolic extract $\left(\mathrm{IC}_{50}=0.027 \mathrm{mg} / \mathrm{mL}\right)$ of Adenosma bracteosum showed a higher inhibitory activity than the aqueous extract $\left(\mathrm{IC}_{50}=0.043 \mathrm{mg} /\right.$ $\mathrm{mL})$. The increased activity was associated with the detection of isoscutellarein-8-O- $\beta$-D-glucopyranoside in the ethanolic extract exhibiting a ten times higher inhibitory activity against alpha-glucosidase $\left(\mathrm{IC}_{50}\right.$ $=1.40 \mu \mathrm{g} / \mathrm{mL}$ ) compared to acarbose (Nguyen et al. 2020). Similarly, the petroleum ether extract of Hertia cheirifolia (L.) $\quad\left(\mathrm{IC}_{50}=0.242 \mathrm{mg} / \mathrm{mL}\right)$ showed a higher inhibitory activity than the ethyl acetate $\left(\mathrm{IC}_{50}=0.437 \mathrm{mg} / \mathrm{mL}\right)$ and butanol $\left(\mathrm{IC}_{50}\right.$ $=0.421 \mathrm{mg} / \mathrm{mL}$ ) extracts. The bioassay-guided fractionation of the petroleum ether extract resulted in the isolation of nopol, which exhibited inhibitory activity with $\mathrm{IC}_{50}$ value of $220 \mu \mathrm{M}$ and higher than acarbose $\left(\mathrm{IC}_{50}=433.70 \mu \mathrm{M}\right)$ (Majouli et al. 2017). The oral administration of up to $2000 \mathrm{mg} / \mathrm{kg}$ of the methanol extract of Hertia cheirifolia did not produce any signs of toxicity in mice for 14 days (Bouriche et al. 2016) suggesting that extracts from this plant can also be potential candidates for the treatment of diabetes.

Quercus plants belonging to the Fagaceae family including Quercus glauca, Quercus gilva, Quercus dentata, and Quercus phillyraeoides displayed a wide range of $\mathrm{IC}_{50}$ values varying from 0.0098 to $0.11 \mathrm{mg}$ / $\mathrm{mL}$ although the extracts were all prepared from leaves by methanol extraction (Ndrianingsih et al. 2015). Other extracts isolated from Mallotus japonicus, Xylosoma congestum, Podocarpus macrophyllus, Annona senegalensis, Homalium zeylanicum, Hypericum hircinum, Hypericum scruglii and Liquidambar formosana that showed an inhibitory activity against alpha-glucosidase are listed in Table 1. The fractionation of the ethanolic extract of Annona senegalensis resulted in the isolaton of a number of compounds 


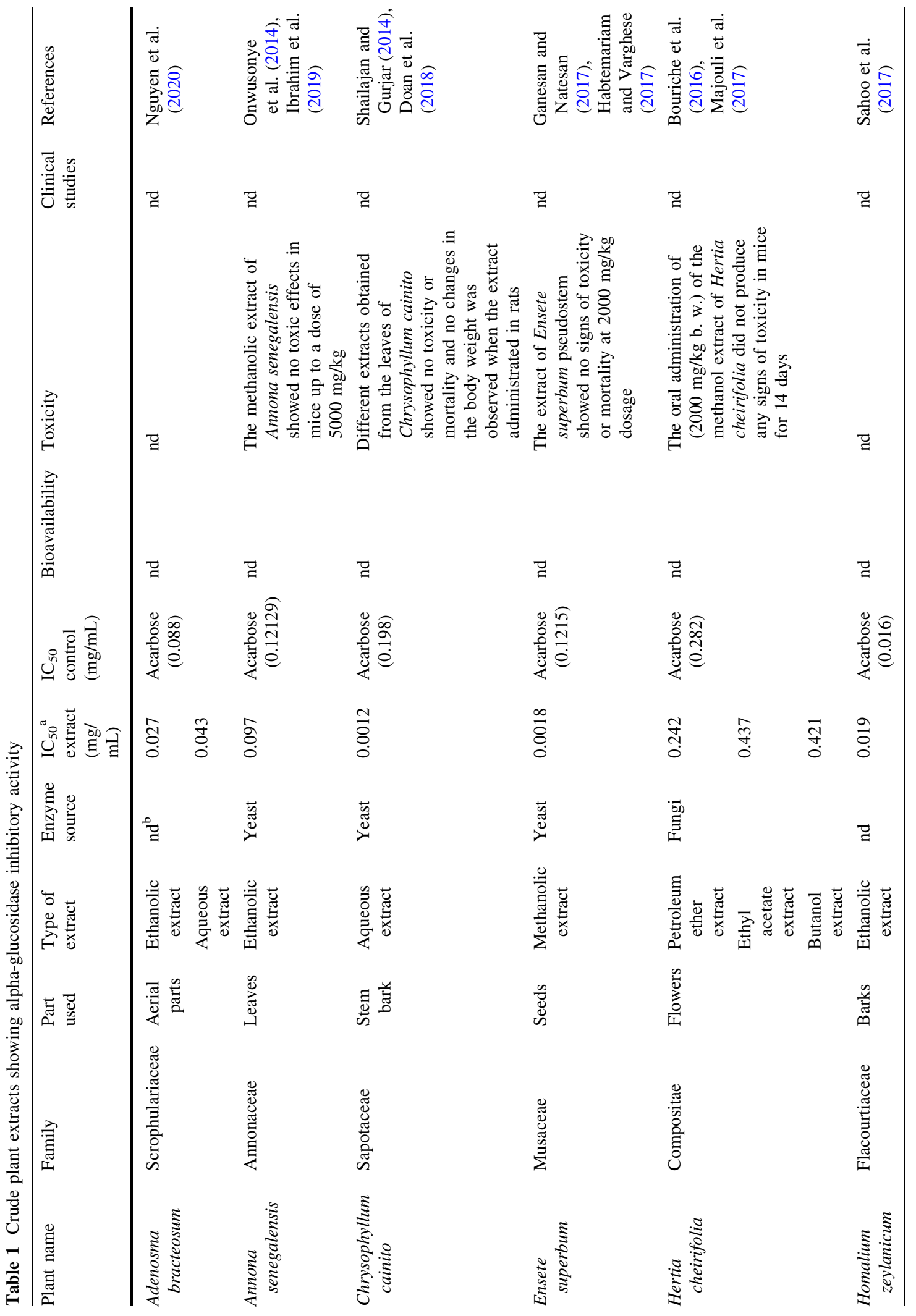




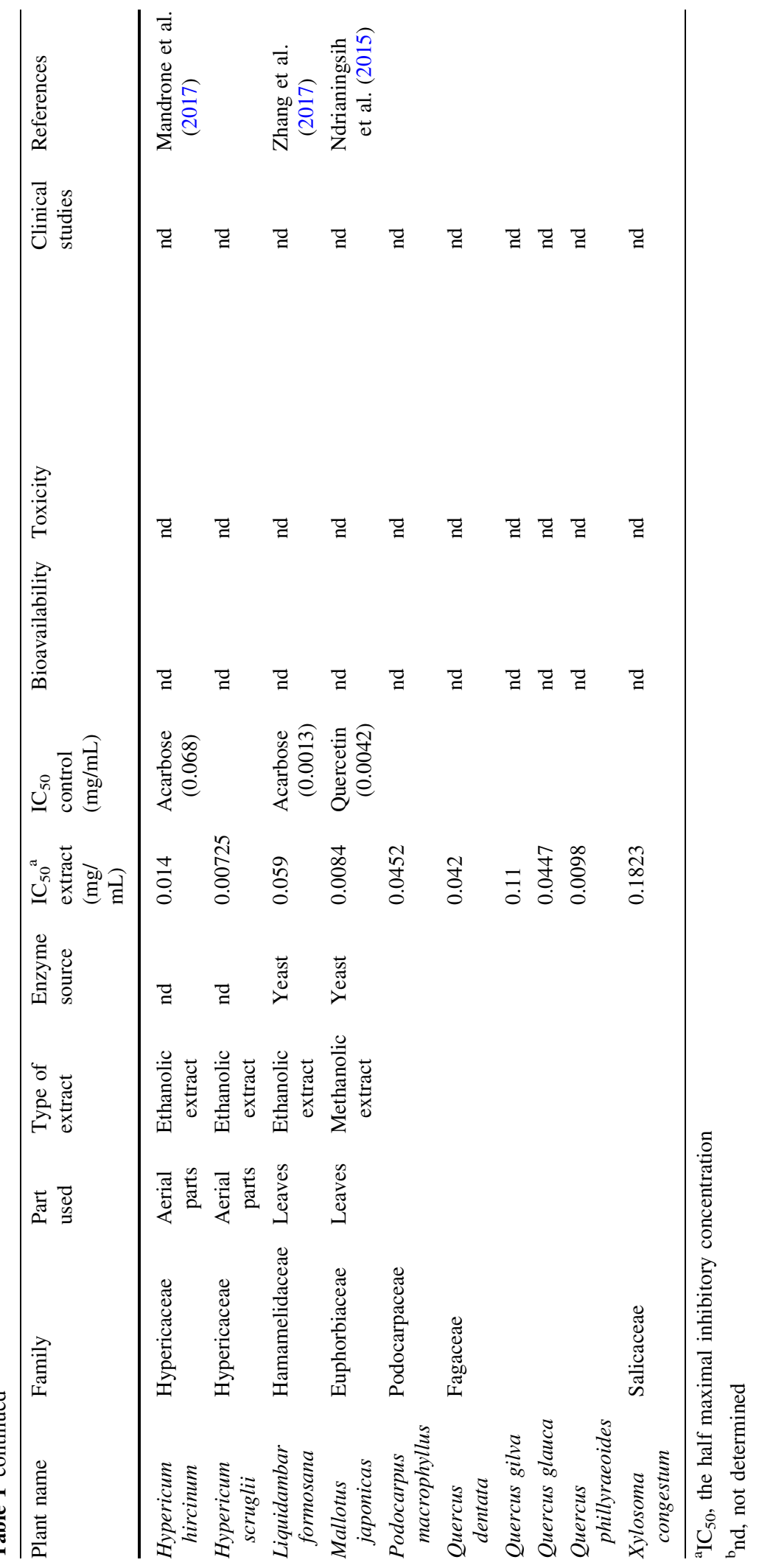


including hexadecanoic acid, methyl ester, 1,3-octadecenal and 1,2- benzenedicarboxylic acid (Ibrahim et al. 2019). The acute oral toxicity of the methanolic extract of the leaves of Annona senegalensis was examined in mice. Results showed that Annona senegalensis has no toxic effects in mice up to a dose of $5000 \mathrm{mg} / \mathrm{kg}$ (Onwusonye et al. 2014). The ethyl acetate fraction of Liquidambar formosana leaf extract was rich in phenolic compounds, tannins and flavonoids (Zhang et al. 2017). Moreover, Hypericum scruglii ethanolic extract was rich in phloroglucinol derivatives namely 3-geranyl-1-(2'-methylbutanoyl)phloroglucinol and 3-geranyl-1-(2'-methylpropanoyl)-phloroglucinol (Mandrone et al. 2017). None of the aforementioned isolated compounds have been tested against alpha-glucosidase enzyme. Overall, plant species that belong to Fagaceae, Euphorbiaceae, Hypericaceae, Musaceae and Sapotaceae families exhibited promising inhibitory activities and further studies evaluating the safety, side effect, and efficacy of these plants as approved treatments for diabetes are required.

Oligopin ${ }^{\circledR}$ and Pycnogenol ${ }^{\circledR}$ are examples of commercially available plant extract dietary supplements. They are French maritime pine bark extracts obtained from the pine tree Pinus pinaster. Initially known for their antioxidant and anti-inflammatory activities (Valls et al. 2016; Sedighiyan et al. 2018). French maritime pine bark extracts have also shown potent alpha-glucosidase inhibitory activity compared to green tea extract and acarbose, and procyanidin oligomers were found to be responsible for this activity (Schäfer and Högger 2007). Some of the identified plants in this review exhibiting alphaglucosidase inhibitory activity are already used as food or ingredient food for thousands of years in the human diet such as the fruit (acorn) of the Quercus species (Ómez et al. 2017) and are likely to be safe candidate for the development of dietary supplements. In addition to alpha-glucosidase inhibition, whole plant preparations contain a wide range of active compounds with anti-inflammatory and antioxidative activities that can improve diabetes health outcomes. Moreover, there are evidence that the synergistic interaction between compounds present in herbal preparation can improve the bioactivity of the crude extract (Reviewed in Rasoanaivo et al. 2011). Whole plants supplements can also be produced locally and at lower costs compared to a single bioactive compound.
However, the production of plant extracts is poorly standardized and controlled due to variations in the extraction methods and formulations leading to variability in the extracted compounds (Kunle et al. 2012). The development of pharmacological methods and clinical studies for the evaluation of the activities and adverse effects induced by the administration of complex mixtures of compounds is also needed (Heinrich 2013). Through the identification and isolation of bioactive phytochemicals, better recovery, purity and selectivity can be achieved in drug research and development.

\section{Plant secondary metabolites as alpha-glucosidase inhibitors}

Secondary plant metabolites with bioactive features are responsible for the pharmaceutical properties of plants. This review reported the alpha-glucosidase inhibitory activity of compounds isolated from 53 plant species that belong to 27 different families (Fig. 2a). Most of the bioactive compounds were from Fabaceae family (33 bioactive compounds), followed by Zingiberaceae (28 bioactive compounds) and Moraceae (25 bioactive compounds) families. Fabaceae family is one of the largest families that comprises 745 genera and more than 19,500 plant species (Wink 2013). Several plants that belong to the Fabaceae family have been utilized in traditional medicine. Moreover, different chemical components with various biological properties have been isolated from species of the Fabaceae family including isoflavonoids, alkaloids, terpenoids and phenolic acids (Ma et al. 2011; Aly et al. 2019). Similarly, compounds isolated from plants belonging to the Zingiberaceae family exhibited a wide range of pharmacological activities such as antioxidant, antiinflammatory and antimicrobial activities (Mao et al. 2019).

The identified phytochemicals showing alpha-glucosidase inhibitory activity were grouped into major categories and subcategories based on their chemical classification (Fig. 2b). Although, terpenes and flavonoids were found to represent the largest chemical classes that exhibited inhibitory activities against this enzyme, the reported $\mathrm{IC}_{50}$ value compared to the positive control was the major criteria for identifying the most bioactive molecules. Accordingly, 8 
Fig. 2 A Bar chart showing the number of bioactive compounds from the different plant families. B Pie chart showing the chemical distribution of selected compounds
A

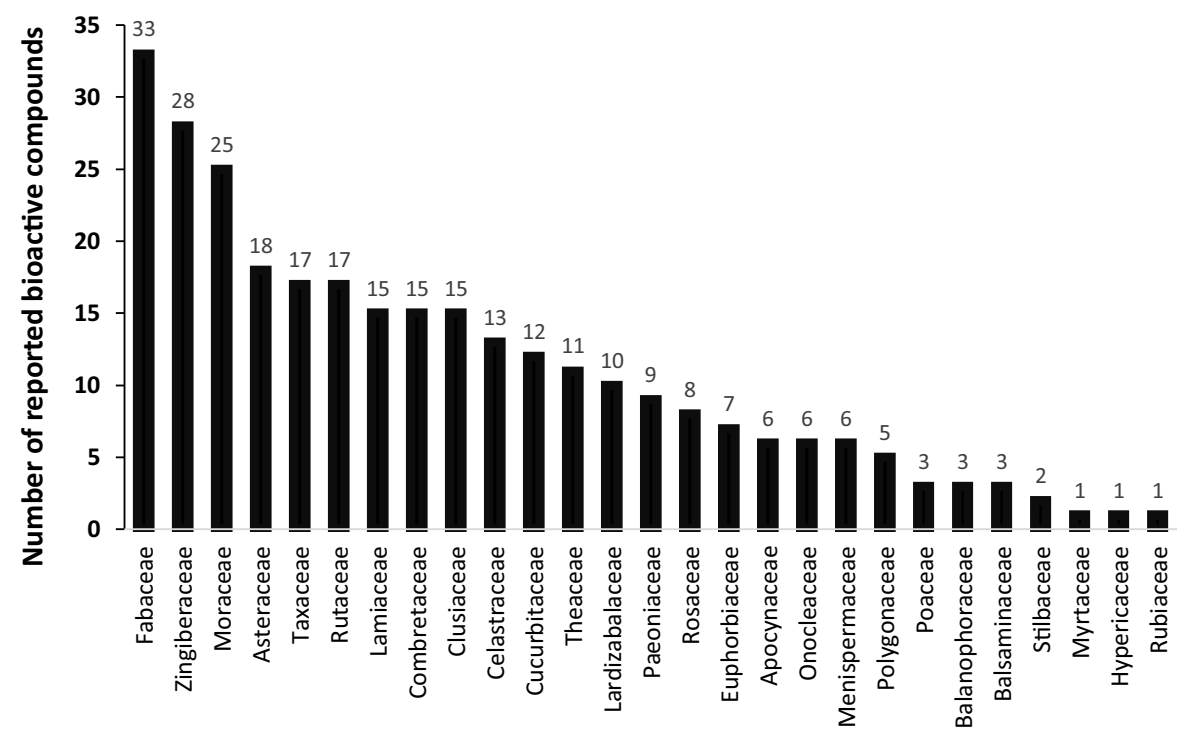

Plant family

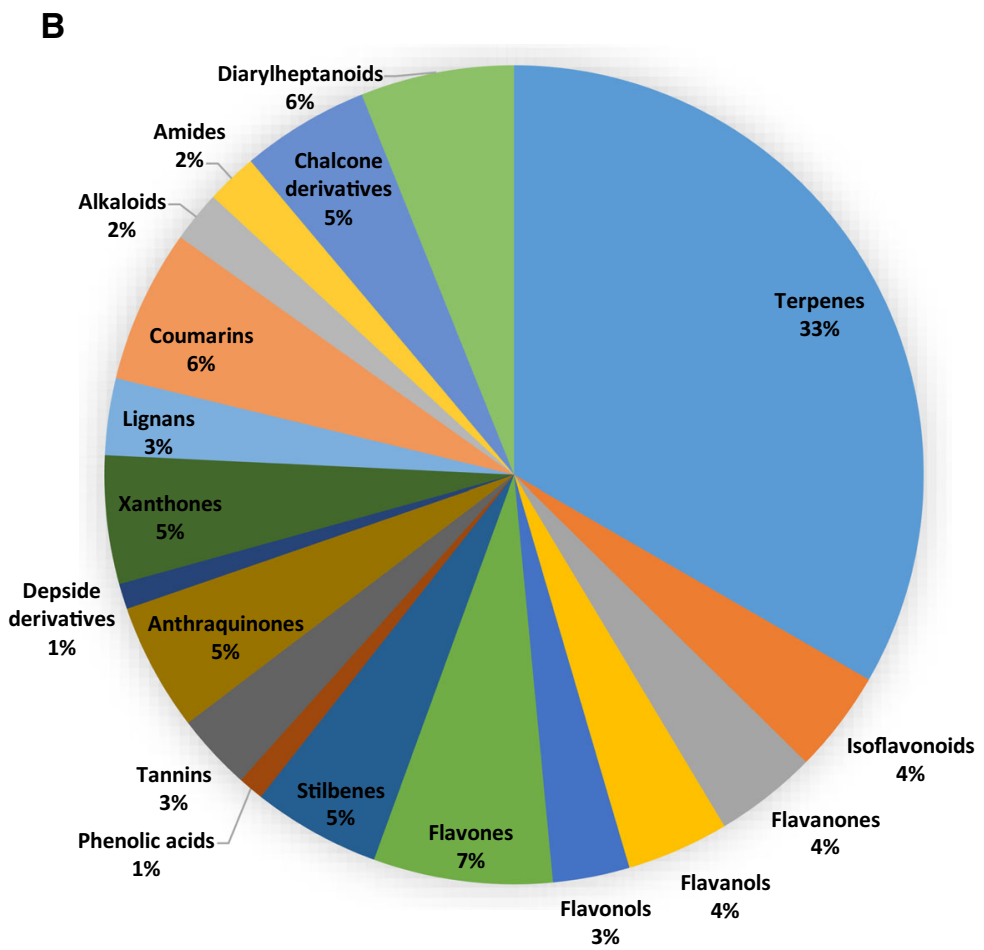

molecules were selected as promising alpha-glucosidase inhibitors and information about their bioactivity, bioavailability and toxicity were covered in detail (Fig. 3; Table 2).
Sesquiterpenoids

Terpenoids captivated a lot of interest due to their distinct biological activities such as anticancer and antibacterial activities (Duru and Çayan 2015). In 


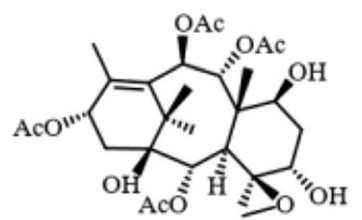

Taxumariene $\mathbf{F}$<smiles>CC(C)=CCc1c(-c2ccc(O)cc2O)oc2c3c(cc(O)c2c1=O)OC(C)(C)C=C3</smiles>

Morusin

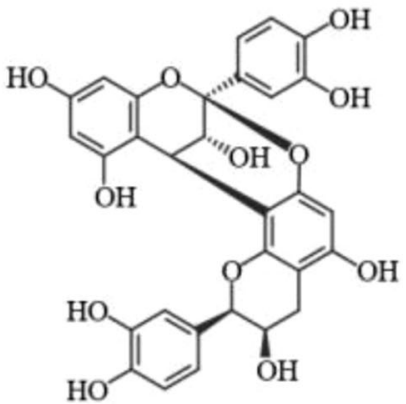

Procyanidin A2

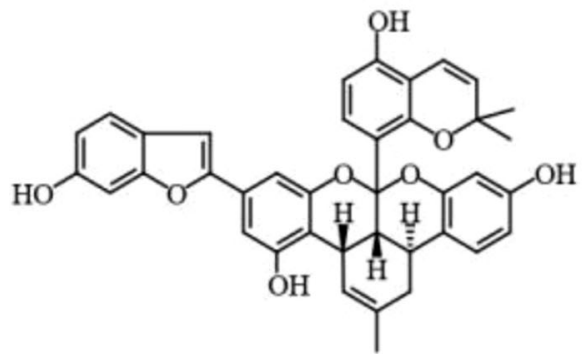

Mulberrofuran $\mathbf{K}$

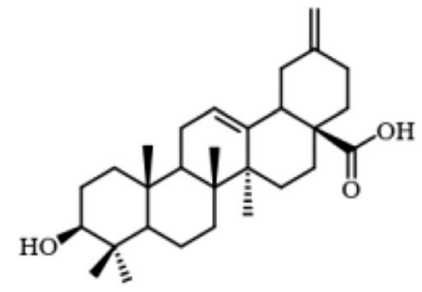

Akebonoic acid<smiles>COc1ccc(/C=C/c2cc(O)cc(OC(O)C(O)C(O)O)c2)cc1O</smiles>

Rhaponticin

Alaternin<smiles>CC(C)=CCc1cc2c(cc1O)oc(=O)c1c3ccc(O)cc3oc21</smiles>

Psoralidin

Fig. 3 Chemical structures of promising alpha-glucosidase inhibitors of plant origin. (Taxumariene F, Akebonoic acid, Morusin, Rhaponticin, Procyanidin A2, Alaternin, Mulberrofuran K and Psoralidin)

terms of pharmaceuticals, a number of commercially available drugs are terpene-derived such as paclitaxel and artemisinin (Bergman et al. 2019). A total of 95 terpenoids with alpha-glucosidase inhibitory activity 


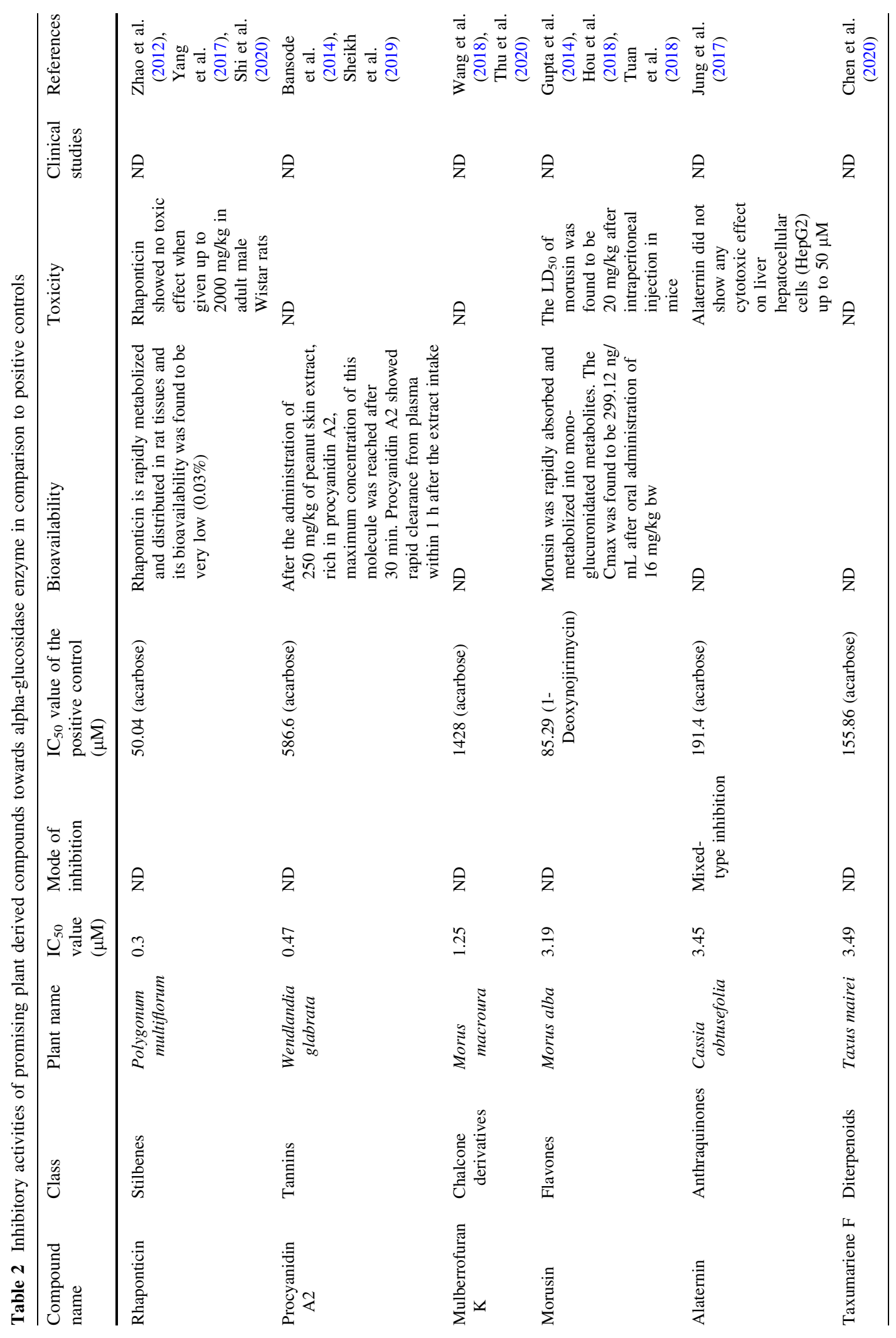







were reported in the form of sesquiterpenoids, diterpenoids and triterpenoids.

Sesquiterpenoids exhibited in general a poor inhibitory activity compared to the positive control except for the novel gorgonane sesquiterpenoid (structure 12; online resource 1 and 2). This molecule $\left(\mathrm{IC}_{50}=121.2 \mu \mathrm{M}\right)$ was isolated from Teucrium mascatense and it showed an inhibitory activity against alpha-glucosidase higher than acarbose $\left(\mathrm{IC}_{50-}\right.$ $=942 \mu \mathrm{M})$. Enzyme inhibition is thought to occur when the hydroxyl groups of this compound interact with amino acids Asp68 and Arg439 in the Saccharomyces cerevisiae alpha-glucosidase enzyme through hydrogen bonding. This compound also forms hydrogen bonding with two water molecules located at positions 1026 and 1102 and the enzyme-inhibitor intereraction resembles the interaction with the hydroxyl groups of the first sugar substrate moiety (Rizvi et al. 2019). However, the kinetics and exact mechanism of inhibition was not determined.

As a newly identified compound, other bioactivities, pharmacokinetics and toxicity studies have not been reported yet for this molecule. In addition, the toxicity was never assessed, and the alpha-glucosidase activity was only investigated in vitro. More research on the pharmacokinetics, the biological activities and preclinical safety are required before considereding the novel gorgonane sesquiterpenoid for clinical trials as anti-diabetic drug.

\section{Diterpenoids}

\section{Alpha-glucosidase inhibition}

Diterpenoids showed comparable to slightly better inhibitory activities against alpha-glucosidase compared to the positive control. However, a series of new taxane-type diterpenoids (structures 28-33, online resource 1 and 2) isolated from Taxus mairei showed promising inhibitory activity against this enzyme (Chen et al. 2020). Taxane-type diterpenoids are considered as the most widely distributed compounds found in the Taxus species (Hai et al. 2014). Among these valuable species, Taxus mairei, which is endemic to china and traditionally have been utilized to treat diabetes (Shen et al. 1998). Several prior investigations on this plant have resulted in the isolation of a myriad of bioactive components including abietane type diterpenoids (Yang et al. 1998), lignans and flavonoids (Yang et al. 1999).

In this review, taxane inhibitors in comparison to acarbose $\quad\left(\mathrm{IC}_{50}=155.86 \mu \mathrm{M}\right)$ were highlighted including taxumariene F (Fig. 3; Table 2) $\left(\mathrm{IC}_{50-}\right.$ $=3.49 \mu \mathrm{M}$ ), taxumariene $\mathrm{D}$ (compound 31 ; online resource 1 and 2) $\left(\mathrm{IC}_{50}=13.52 \mu \mathrm{M}\right)$ and taxumariene $\mathrm{C}$ (compound 30; online resource 1 and 2) $\left(\mathrm{IC}_{50-}\right.$ $=16.54 \mu \mathrm{M})$. Compared to the other analogues examined in the same study, the presence of an epoxide group and an acetoxy group at C-9 rather than C-7 enhanced the inhibitory activity of taxumariene F. The reduced inhibitory activity of taxumariene $\mathrm{C}$ could be also attributed the the presence of benzoyloxy group attached at $\mathrm{C}-5$. Replacing this group by $\mathrm{N}-$ methylacetamide phenyl isoserine significantly increased the activity in the case of taxumariene A (compound 28; online resource 1 and 2).

\section{Other bioactivities}

The emergence of taxane-type diterpenoids as clinically effective anticancer drug (paclitaxel and docetaxel) has provoked substantial interest to discover other novel and practical sources of this molecule and its derivatives (Shen et al. 1998). All taxumariene diterpenoids described above were also assessed for their cytotoxicity against two tumor cell lines including human colon carcinoma (HT-29) and human lung adenocarcinoma (A549), and they showed no cytotoxic activity (Chen et al. 2020). The selectivity of these molecules towards the anti-diabetic activity is important in considering taxumariene $\mathrm{F}$ for future drug development.

\section{Pharmacokinetics and toxicity}

The taxane-type diterpenoids reported in this study are newly identified compounds and no pharmacological or pharmacokinetic studies have been reported yet. They represent the second example of natural toxoids exhibiting alpha-glucosidase inhibitory activity after the six wallitaxanes (A-F) isolated from Taxus wallichiana (Dang et al. 2017). Nevertheless, the pharmacokinetic and toxicological aspects of natural and semi-synthetic Taxus-derived compounds have been comprehensively reviewed in (Hao et al. 2018). The anti-cancer drugs Taxol and Taxotere for instance have dose-dependent toxicities causing 
myelosuppression, peripheral sensory neuropathy, allergy, and taxane resistance (Yared and Tkaczuk 2012). A newer generation of taxane drugs (BMS275183, milataxel, ortataxel and tesetaxel) exhibited significantly lower toxicity and hypersensitivity in preclinical and clinical studies (Flores and Saif 2013). However, the the activity of such molecules as alphaglucosidase inhibitors was never assessed. In addition, during the lengthly development of paclitaxel and docetaxel as anti-cancer agents, experiments showed that these molecules are non-water-soluble making their delivery more challenging (Singla et al. 2002). Through controlled drug delivery using carrier systems such as nanocarriers, liposomes, solid lipid nanoparticles, nanoemulsions, nanocapsules and hydrogels better cellular absorption and safety was achieved (Mahajan et al. 2015). In addition, extensive structure modification of taxanes has proved to generate new molecules with improved therapeutic index (Hu et al. 2014). The availability and large-scale production of these molecules is another obstacle to overcome. Taxanes accumulate in plants at very low concentrations making their extraction very costly and presenting considerable environmental concerns as their production requires massive amounts of plant biomass. To overcome taxane supply crisis chemical synthesis, plant tissue cultures and microbial fermentation methods have been used (Shankar Naik 2019).

The alpha-glucosidase inhibitory activity of these molecules was so far only investigated in vitro. Considering the available information of structurally similar molecules, the pharmacokinetic and pharmacodynamic properties of taxumariene alpha-glucosidase inhibitors should be judged carefully in the process of novel drug design. The rapid development in discovering and enhancing the activities of taxane analogs as anti-cancer drugs, and the presence of online databases providing information on discovered taxanes and their properties (Murugan et al. 2015), can significantly support research development.

Triterpenoids

\section{Alpha-glucosidase inhibition}

Triterpenoids are polymers of six isoprene units with versatile biological properties and are ubiquitously found in plants as free acids or aglycones (Yin 2015). However, very few triterpenoids showed higher inhibitory activity compared to the positive control acarbose. Molecules with promising activies belonged to the plant families Lamiaceae and Lardizabalaceae. Oleanolic acid, ursolic acid, $\beta$-amyrin and 11,12dehydroursolic acid lactone (compounds 65-68; online resource 1 and 2) isolated from Salvia africana-lutea exhibited promising alpha-glucosidase inhibitory activity with $\mathrm{IC}_{50}$ values in the range of 24.7-188.7 $\mu \mathrm{M}$ compared to $945.5 \mu \mathrm{M}$ for acarbose (Etsassala et al. 2019). The presence of a methyl group at the C-19 position had a positive effect on the inhibitory activity of ursolic acid.

Interestingly, despite being structuraly very similar, triterpenoids isolated from Akebia trifoliata (compounds 80-88; online resource 1 and 2) showed a broad variation in the reported $\mathrm{IC}_{50}$ against alphaglucosidase (9-592 $\mu \mathrm{M}$ ) (Ouyang et al. 2018). While compounds 83 and 84 showed comparable $\mathrm{IC}_{50}$ values and low inhibitory activity, the structurally similar compound gypsogenic acid (87) exhibited significantly higher inhibition that can be attribituted to the presence of a carboxy group at positions 23. The pentacyclic triterpenoid, akebonoic acid, was also remarkably efficient with an $\mathrm{IC}_{50}$ value of $9 \mu \mathrm{M}$ compared to $409 \mu \mathrm{M}$ for acarbose (Fig. 3; Table 2). Pentacyclic triterpenes are bioactive triterpenoids and are natural component in many medicinal plants and food sources such as fruits and vegetables. Further investigation on the enzyme inhibition kinetics of this compound demonstrated mixed-type inhibition against $\alpha$-glucosidase $\left(K_{i}=7.70 \mu \mathrm{M}\right)$. Akebonoic acid was found to interact with the enzyme via hydrogen bonding and hydrophobic interactions. In addition to $\alpha$-glucosidase inhibition, this molecule was found to significantly increase glucose uptake in insulin resistant human liver hepatocellular carcinoma (HepG2) cells (Wang et al. 2007). The dual antidiabetic activity of akebonoic acid makes of it a promising candidate for future preclinical and clinical investigations for the treatment of diabetes.

\section{Other bioactivities}

Ursolic acid has previously shown strong anti-obesity and anti-diabetic effects in humans and animals by inhibiting pancreatic $\alpha$-amylase activity, improving insulin sensitivity, and regulating hepatic lipid accumulation (reviewed in Seo et al. 2018). However, ursolic acid prolonged administration is associated 
with adverse effects, notably hepatic cytotoxicity (Wüpper et al. 2020) which is problematic for the treatment of chronic diseases such as diabetes. Oleanolic acid derivative bardoxolone methyl was also evaluated in a phase 3 study for chronic kidney disease in type 2 diabetic patients. The drug caused cardiac side effects leading to the interruption of the trial (de Zeeuw et al. 2013). Oral administration of $\beta$ amyrin in diabetic mice has shown a significant antihyperglycemic and hypolipidemic effects (Santos et al. 2012) yet the safety of this molecule still needs to be determined to allow its use in clinical trials.

The information related to the other biological activities of akebonoic acid is scarce. Nevertheless, Bian et al. (2021) have recently shown that akebonoic acid had no cytotoxic effect on HepG2 cells at a concentration range of 6.25 to $25 \mu \mathrm{M}$. The cytotoxic activity of this molecules was also investigated on different cancer cell lines and the results have shown that akebonoic acid exhibited cytotoxic effects against human lung adenocarcinoma (A549) and human cervical carcinoma (HeLa) cell lines with $\mathrm{IC}_{50}$ values of 49.48 and 28.63 respectively (Wang et al. 2014), significantly higher than the reported $\mathrm{IC}_{50}$ against alpha-glucosidase. In addition, this molecule displayed strong in vitro bacteriostatic activity against Gram positive bacteria, notably methicillin-resistant Staphylococcus aureus (Wang et al. 2014).

\section{Pharmacokinetics and toxicity}

By examining the pharmacokinetic properties and bioavailability of structurally similar pentacyclic triterpenes such as asiatic acid (Yuan et al. 2015), maslinic acid (Sánchez-González et al. 2014) and oleanolic acid (Jeong et al. 2007), these molecules have shown poor water solubility, low bioavailability, and metabolic instability. However, different approaches have been developed to modify and enhance the challenging physicochemical properties of these compounds including nanotechnology ( $\mathrm{Xi}$ et al. 2009) and the development of prodrugs of these triterpenes (Cao et al. 2013). Taking into consideration the advancements on structurally similar molecules can accelerate the development process of an antidiabetic akebonoic acid-based drug. The toxicity and adverse effects associated with the administration of this molecule still need to be investigated before considering akebonoic acid as a promising candidate for drug design.

Flavonoids

Flavonoids are among the largest group that exhibitied alpha-glucosidase inhibitory activty (65 molecules). Flavanoids are hydroxylated phenolic compounds that are ubiquitously found in plants and include isoflavonoids, flavanones, flavanols, flavonols and flavones subclasses. While flavanols were less efficient in inhibiting alpha-glucosidase compared to acarbose, several molecules belonging to the other subclasses showed higher efficiency compared to positive controls.

\section{Alpha-glucosidase inhibition}

One remarkable source of potent inhibitors was the plant Morus alba. Flavones extracted from this plant showed $\mathrm{IC}_{50}$ values up to 30 -fold lower than that reported for the positive control ( $\mathrm{Li}$ et al. 2018; Ha et al. 2018). Significant inhibition was observed with the widely studied flavone, morusin $\left(\mathrm{IC}_{50}=3.19 \mu \mathrm{M}\right)$ compared to 1-Deoxynojirimycin $\left(\mathrm{IC}_{50}=85.29 \mu \mathrm{M}\right)$ (Fig. 3; Table 2) ( $\mathrm{Li}$ et al. 2018). The chemical structure of this molecule involves the presence of a prenyl group at position 3, three hydroxyl groups at $\mathrm{C}-5, \mathrm{C}-2^{\prime \prime}$ and C-4' and a 2,2-dimethyl pyran unit between $\mathrm{C}-7$ and $\mathrm{C}-8$. The prenyl group at position 3 has an enhancing effect on the inhibitory activity of flavones with compounds 151, 156 and 157 also showing significantly lower $\mathrm{IC}_{50}$ vlaues compared to acarbose (online resource 1 and 2). The increase in $\alpha$ glucosidase inhibitory activity with the increase in the number of unmodified prenylated groups was previously reported in the case of six prenylated flavonols isolated from the roots of Dorstenia psilurus (Tabopda et al. 2008).

\section{Other bioactivities}

In addition to its inhibitory activity against alphaglucosidase, morusin also showed an inhibitory activity against acetylcholinesterase $\left(\mathrm{IC}_{50}=36.4 \mu \mathrm{M}\right)$ and butyrylcholinesterase $\left(\mathrm{IC}_{50}=24.08 \mu \mathrm{M}\right)$ (Kim et al. 2011), however, $\mathrm{IC}_{50}$ values reveals a higher selectivity towards alpha-glucosidase enzyme. 
Among other bioactivities, morusin acted as antitumor agent against different types of cancer including colorectal cancer (Lee et al. 2008), liver cancer (Wan et al. 2014), prostate cancer (Lim et al. 2015) and gastric cancer (Wang et al. 2017) (Table 3). The anticancer mechanisms of morusin in the aforementioned cancer types involved apoptosis induction, inhibition of nuclear factor kappa B (NF- $\kappa \mathrm{B})$ activity (Lee et al. 2008), and the inactivation of signal transducer and activator of transcription 3 (STAT3) signaling (Lim et al. 2015). Morusin also showed antibacterial activity against Enterococcus faecalis greater than the standard antibiotics ampicillin and ciprofloxacin (Čulenová et al. 2020).

\section{Pharmacokinetics and toxicity}

The absorption and disposition of morusin was studied by (Hou et al. 2018) in vitro and in vivo in rats. Following an oral administration of $16 \mathrm{mg} / \mathrm{kg}$, morusin was rapidly absorbed and metabolized into monoglucuronidated metabolites. The maximum concentration (Cmax) was $299.12 \mathrm{ng} / \mathrm{mL}$ and occurred at Tmax of 33.33 min, with an AUC0- $\infty$ of $99.28 \mathrm{~min} \mu \mathrm{g} / \mathrm{mL}$ and a half-life time of $370.35 \mathrm{~min}$. Additionally, plasma concentration-time profiles of morusin and its metabolites displayed two peaks after oral administration which can be attributed to enterohepatic re-circulation. Concerning metabolism, morusin was subjected into extensive glucuronidation in vitro and in vivo. The glucuronidation metabolism of morusin was mediated by four enzymes namely UDP-glucuronosyltransferases (UGT1A1, UGT1A3, UGT1A7 and UGT2B7). Majority of these enzymes are primarily expressed in the liver and intestine suggesting that these organs are the main organs that heavily contribute to morusin glucuronidation. Furthermore, morusin undergo phase I oxidative metabolism catalyzed by Cytochrome $\mathrm{P} 450$ enzymes (CYP3A5, CYP3A4 and CYP2C19). The metabolism of this molecule in the liver and intestine is an important aspect in considering it as a drug candidate. However, morusin also showed potent inhibition against the drug-metabolizing enzymes CYP450s and UGTs, including CYP3A4 which is involved in the metabolism of over $50 \%$ of clinically used drugs (Shi et al. 2016a). Drug-drug interaction of morusin with frequently administered medication for type 2 diabetes should be therefore carefully investigated during the development of morusin-derived antidiabetic drug. The acute toxicity of morusin was also examined in vivo in mice after an intraperitoneal administration at $1.75,5.5,17.5,55 \mathrm{mg} / \mathrm{kg}$ dosages (Gupta et al. 2014). The lethal dose $\left(\mathrm{LD}_{50}\right)$ of this compound was found to be $20 \mathrm{mg} / \mathrm{kg}$.

The optimal equilibrium between metabolism, therapeutic effect, and controlled toxicity of morusin during alpha-glucosidase inhibition is therefore a key aspect to be studied in the furture. The hydrophobicity and low bioavailability of this compound also hinder its clinical application. However, some endeavors have been undertaken to enhance the bioavailability of this compound. Among these strategies was the synthesis of a niosome system consisting of non-ionic surfactant span 60 and cholesterol utilizing a thinlayer evaporation technique (Agarwal et al. 2018). Interestingly, the nanomorusin exhibited better water solubility and anti-cancer activity than the free form of morusin. It is therefore interesting to investigate nanomorusin efficiency in inhibiting alpha-glucosidase in vitro and in animal models.

\section{Chalcones derivatives}

Chalcones are naturally occurring aromatic ketones that possess distinct pharmacological activities such as anti-cancer and anti-diabetic activities. Plant species of the genus Morus are rich in phenolic compounds particularly Diels-Alder type adducts and isoprenylated flavonoids. The Morus genus consists of 16 distinct species that are utilized in traditional Chinese medicine for the treatment of different diseases. The root bark of Morus macroura for example have been traditionally used to treat different ailments including rheumatism, arthritis and diabetes (Dai et al. 2004).

\section{Alpha-glucosidase inhibition}

Nine Diels-Alder type adducts (compounds 162-169; online resource 1 and 2) were isolated from Morus macroura and evaluated against alpha-glucosidase enzyme (Wang et al. 2018). Among the isolated compounds, mulberrofuran K (Fig. 3; Table 2), sorocein I (compound 169; online resource 1 and 2) and macrourin $\mathrm{J}$ (compound 163; online resource 1 and 2) were the most active compounds, with $\mathrm{IC}_{50}$ values of $1.25,1.47$ and $1.58 \mu \mathrm{M}$, respectively compared to $1428 \mu \mathrm{M}$ for acarbose. The inhibition mechanism of 
Table 3 Polypharmacological properties of promising alpha-glucosidase inhibitors

\begin{tabular}{|c|c|c|c|}
\hline $\begin{array}{l}\text { Compound } \\
\text { name }\end{array}$ & Bioactivity & Key findings & References \\
\hline \multirow[t]{7}{*}{ Rhaponticin } & \multirow[t]{2}{*}{$\begin{array}{l}\text { Anti-cancer } \\
\text { activity }\end{array}$} & $\begin{array}{l}\text { Inhibited the growth of stomach cancer cells through apoptosis induction, } \mathrm{IC}_{50} \\
(0-200 \mu \mathrm{M})\end{array}$ & $\begin{array}{l}\text { Hibasami et al. } \\
\text { (2007) }\end{array}$ \\
\hline & & $\begin{array}{l}\text { Inhibited the activity of FAS and down-regulated its expression in human breast } \\
\text { cancer cells, } \mathrm{IC}_{50}(0-400 \mu \mathrm{M})\end{array}$ & Li et al. (2014) \\
\hline & $\begin{array}{l}\text { Anti- } \\
\text { inflammatory } \\
\text { activity }\end{array}$ & Exhibited LOX inhibitory activity $\left(\mathrm{IC}_{50}=34.3 \mu \mathrm{M}\right)$ & $\begin{array}{l}\text { (Ngoc et al. } \\
\text { 2008) }\end{array}$ \\
\hline & \multirow[t]{3}{*}{$\begin{array}{l}\text { Neuroprotective } \\
\text { effect }\end{array}$} & \multirow{2}{*}{$\begin{array}{l}\text { Anti-Parkinson's disease activity: Inhibited the production of proinflammatory } \\
\text { mediators such as NO, PGE } 2 \text {, TNF- } \alpha \text {, IL- } 1 \beta \text {, IL- } 6 \text {, and ROS in LPS-induced } \\
\text { microglial cells }(10,25 \text { and } 50 \mu \mathrm{M}) \text {. Rhaponticin improved motor impairments and } \\
\text { prevented the damage of dopaminergic neurons in vivo }\end{array}$} & $\begin{array}{l}\text { Zhao et al. } \\
\text { (2020) }\end{array}$ \\
\hline & & & $\begin{array}{l}\text { Misiti et al. } \\
\text { (2006) }\end{array}$ \\
\hline & & $\begin{array}{l}\text { Anti-Alzheimer's disease activity: Exhibited protective effect against } \mathrm{A} \beta \text { peptide- } \\
\text { induced apoptosis in human neuroblastoma cells, } \mathrm{IC}_{50}(0-30 \mu \mathrm{M}) \text {. This effect is } \\
\text { probably mediated through the up-regulation of bcl- } 2 \text { and the down-regulation of } \\
\text { Bax }\end{array}$ & \\
\hline & $\begin{array}{l}\text { Anti-diabetic } \\
\text { activity }\end{array}$ & $\begin{array}{l}\text { Reduced glucose levels, enhanced glucose tolerance and impeded hepatic fibrosis } \\
\text { and steatosis in vivo }(125 \mathrm{mg} / \mathrm{kg})\end{array}$ & $\begin{array}{l}\text { Chen et al. } \\
\text { (2009) }\end{array}$ \\
\hline \multirow[t]{5}{*}{$\begin{array}{l}\text { Procyanidin } \\
\text { A2 }\end{array}$} & $\begin{array}{l}\text { Anti- } \\
\text { inflammatory } \\
\text { activity }\end{array}$ & $\begin{array}{l}\text { Showed an inhibitory action against cytokine stimulated-CCL11 production in lung } \\
\text { epithelial cells, } \mathrm{IC}_{50}(1-20 \mu \mathrm{M})\end{array}$ & $\begin{array}{l}\text { Coleman et al. } \\
\text { (2016) }\end{array}$ \\
\hline & $\begin{array}{l}\text { Neuroprotective } \\
\text { effect }\end{array}$ & $\begin{array}{l}\text { Prevented }(10 \mu \mathrm{M}) \text { neuroinflammation by inhibiting pro-inflammatory mediators and } \\
\text { suppressed apoptosis through the up-regulation of bcl-2 and the down-regulation of } \\
\text { Bax in A } \beta(1-42) \text { induced BV-2 cells }\end{array}$ & $\begin{array}{l}\text { Tang et al. } \\
\text { (2018) }\end{array}$ \\
\hline & Antiviral activity & Exhibited an inhibitory activity against SARS-CoV infection $\left(\mathrm{IC}_{50}=29.9 \mu \mathrm{M}\right)$ & $\begin{array}{l}\text { Zhuang et al. } \\
\text { (2009) }\end{array}$ \\
\hline & $\begin{array}{l}\text { Anti-oxidant } \\
\text { activity } 1\end{array}$ & $\begin{array}{l}\text { Prevented } t \text {-BOOH oxidative stress through the inhibition of ROS generation, } \\
\text { inhibition of LDH production and the up-regulation of HO- } 1 \text { and NQO1 expression } \\
\text { through the activation of Nrf } 2 \text { via JNK and p38 signaling pathway, } \mathrm{IC}_{50}(0-40 \mu \mathrm{M})\end{array}$ & $\begin{array}{l}\text { Xu et al. } \\
\text { (2019) }\end{array}$ \\
\hline & & Exhibited a potent inhibitory activity against $\mathrm{LDL}$ oxidation $\left(\mathrm{IC}_{50}=2.1 \mu \mathrm{M}\right)$ & $(2014)$ \\
\hline \multirow[t]{3}{*}{$\begin{array}{l}\text { Mulberrofuran } \\
\mathrm{K}\end{array}$} & $\begin{array}{l}\text { Anti-diabetic } \\
\text { activity }\end{array}$ & Exhibited potent PTP1B inhibitory activity $\left(\mathrm{IC}_{50}=8.49 \mu \mathrm{M}\right)$ & $\begin{array}{r}\text { Ha et al. } \\
(2018)\end{array}$ \\
\hline & $\begin{array}{l}\text { Anti- } \\
\text { inflammatory } \\
\text { activity }\end{array}$ & $\begin{array}{l}\text { Inhibited the generation of proinflammatory mediators including NO, TNF- } \alpha, \mathrm{IL}-1 \beta \text {, } \\
\text { IL-6, and ROS. Inhibited the expression of iNOS and COX-2 and the } \\
\text { transcriptional activation of NF- } \mathrm{B} \text { B and ERK } 1 / 2, \mathrm{IC}_{50}(0-10 \mu \mathrm{M})\end{array}$ & $\begin{array}{l}\text { Shim et al. } \\
\text { (2018) }\end{array}$ \\
\hline & $\begin{array}{l}\text { Neuroprotective } \\
\text { effect }\end{array}$ & $\begin{array}{l}\text { Inhibited NO production }\left(\mathrm{IC}_{50}=7.1 \mu \mathrm{M}\right) \text { and tau protein aggregation }(20 \mu \mathrm{M}) \text {. } \\
\text { Exhibited neuroprotective effect through the up-regulation of } \mathrm{GSH} \text { level and the } \\
\text { inhibition of ROS generation in glutamate-stimulated HT22 cells }(0.5,1 \text {, and } \\
2 \mu \mathrm{M})\end{array}$ & $\begin{array}{l}\text { Xia et al. } \\
\text { (2019) }\end{array}$ \\
\hline \multirow[t]{7}{*}{ Morusin } & \multirow{5}{*}{$\begin{array}{l}\text { Anti-cancer } \\
\text { activity }\end{array}$} & Colorectal cancer: Induced apoptosis and inhibited $\mathrm{NF}_{-\mathrm{k}} \mathrm{B}$ activity & Lee et al. \\
\hline & & Prostate cancer: Induced apoptosis through the inhibition of STAT3 signaling & \\
\hline & & $\begin{array}{l}\text { Liver cancer: Suppressed tumor growth in mice via the up-regulation of caspase- } 3 \\
\text { and the down-regulation of } \mathrm{NF}_{-\mathrm{k}} \mathrm{B} \text { gene expression }\end{array}$ & $\begin{array}{l}\text { Lim et al. } \\
\text { (2015) }\end{array}$ \\
\hline & & \multirow[t]{2}{*}{$\begin{array}{l}\text { Gastric cancer: Inhibited tumor growth through the down-regulation of } \\
\text { myelocytomatosis (c-Myc) expression }\end{array}$} & $\begin{array}{l}\text { Wan et al. } \\
\text { (2014) }\end{array}$ \\
\hline & & & $\begin{array}{l}\text { Wang et al. } \\
\text { (2017) }\end{array}$ \\
\hline & $\begin{array}{l}\text { Neuroprotective } \\
\text { activity }\end{array}$ & $\begin{array}{l}\text { Showed inhibitory activity against } \mathrm{AChE} \text { and } \mathrm{BChE} \text { with } \mathrm{IC}_{50} \text { value of } 36.4 \text { and } \\
24.08 \mu \mathrm{M} \text {, respectively }\end{array}$ & $\begin{array}{l}\text { Kim et al. } \\
\quad(2011)\end{array}$ \\
\hline & $\begin{array}{l}\text { Anti- } \\
\text { inflammatory } \\
\text { activity }\end{array}$ & Exhibited protective effect against TNBS-stimulated colitis in rats & $\begin{array}{l}\text { Vochyánova } \\
\text { et al. (2017) }\end{array}$ \\
\hline
\end{tabular}


Table 3 continued

\begin{tabular}{|c|c|c|c|}
\hline $\begin{array}{l}\text { Compound } \\
\text { name }\end{array}$ & Bioactivity & Key findings & References \\
\hline \multirow[t]{8}{*}{ Alaternin } & $\begin{array}{l}\text { Anti-diabetic } \\
\text { activity }\end{array}$ & Exhibited potent PTP1B inhibitory activity $\left(\mathrm{IC}_{50}=1.22 \mu \mathrm{M}\right)$ & $\begin{array}{l}\text { Jung et al. } \\
\text { (2017) }\end{array}$ \\
\hline & $\begin{array}{l}\text { Anti-oxidant } \\
\text { actvity }\end{array}$ & Exhibited potent peroxynitrite scavenging activity with $\mathrm{IC}_{50}$ value of $2.70 \mu \mathrm{M}$ & $\begin{array}{l}\text { Park et al. } \\
\quad(2004)\end{array}$ \\
\hline & \multirow{2}{*}{$\begin{array}{l}\text { Hepatoprotective } \\
\text { activity }\end{array}$} & Exhibited hepatoprotective effects & \multirow{2}{*}{$\begin{array}{l}\text { Jung et al. } \\
\text { (2004) }\end{array}$} \\
\hline & & $\begin{array}{l}\text { on tacrine-mediated cytotoxicity in liver cells with } \mathrm{EC}_{50} \text { value of } 4.02 \mu \mathrm{M} \text { on tacrine } \\
\text {-induced cytotoxicity }\end{array}$ & \\
\hline & \multirow[t]{3}{*}{$\begin{array}{l}\text { Neuroprotective } \\
\text { activity }\end{array}$} & $\begin{array}{l}\text { Exhibited mixed-type inhibitory activity against both hMAO enzyme isozymes, } \\
\text { hMAO-A }\left(\mathrm{IC}_{50}=5.35 \mu \mathrm{M}\right) \text {, and hMAO-B }\left(\mathrm{IC}_{50}=4.55 \mu \mathrm{M}\right)\end{array}$ & $\begin{array}{l}\text { Paudel et al. } \\
\text { (2019) }\end{array}$ \\
\hline & & $\begin{array}{l}\text { Showed inhibitory activity against } \mathrm{AChE}, \mathrm{BChE} \text { and } \mathrm{BACE} 1 \text { with } \mathrm{IC}_{50} \text { value of } \\
21.9,394.77 \text { and } 3.28 \mu \mathrm{M} \text {, respectively }\end{array}$ & $\begin{array}{l}\text { Jung et al. } \\
\quad(2016)\end{array}$ \\
\hline & & $\begin{array}{l}\text { Alaternin }(10 \mathrm{mg} / \mathrm{kg}) \text { inhibited nitrotyrosine and lipid peroxidation. Suppressed the } \\
\text { expression of iNOS and decreased microglial activation in vivo }\end{array}$ & $\begin{array}{l}\text { Shin et al. } \\
\text { (2010) }\end{array}$ \\
\hline & $\begin{array}{l}\text { Antityrosinase } \\
\text { activity }\end{array}$ & $\begin{array}{l}\text { Inhibited tyrosinase enzyme activity with } \mathrm{IC}_{50} \text { value of } 327.3 \mu \mathrm{M} \text { after } 30 \mathrm{~min} \text { of } \\
\text { incubation }\end{array}$ & $\begin{array}{l}\text { Lu and Ko } \\
\quad(2016)\end{array}$ \\
\hline \multirow[t]{5}{*}{ Psoralidin } & $\begin{array}{l}\text { Estrogenic } \\
\text { activity }\end{array}$ & Psoralidin was found to be a potent $\operatorname{ER} \alpha$ and $\operatorname{ER} \beta$ agonist & $\begin{array}{l}\text { Liu et al. } \\
\quad(2014)\end{array}$ \\
\hline & \multirow[t]{3}{*}{$\begin{array}{l}\text { Anti-cancer } \\
\text { activity }\end{array}$} & $\begin{array}{l}\text { Breast cancer: Induced DNA damage and autophagy through NOX4-mediated ROS } \\
\text { production, } \mathrm{IC}_{50}(0-10 \mu \mathrm{M})\end{array}$ & $\begin{array}{l}\text { Ren et al. } \\
\quad(2016)\end{array}$ \\
\hline & & $\begin{array}{l}\text { Colon cancer: Apoptosis induction through the suppression of Bcl-2/Bax and NF-kB } \\
\text { signaling pathways, } \mathrm{IC}_{50}(0-20 \mu \mathrm{M})\end{array}$ & $\begin{array}{r}\text { Jin et al. } \\
(2016)\end{array}$ \\
\hline & & $\begin{array}{l}\text { Liver cancer: Apoptosis induction via intrinsic and extrinsic pathways, } \mathrm{IC}_{50} \\
(0-64 \mu \mathrm{M})\end{array}$ & $\begin{array}{l}\text { Bin et al. } \\
\text { (2019) }\end{array}$ \\
\hline & $\begin{array}{l}\text { Anti- } \\
\text { inflammatory } \\
\text { activity }\end{array}$ & $\begin{array}{l}\text { Exhibited an inhibitory activity against LPS-stimulated NO production, } \\
\left(\mathrm{IC}_{50}=27.46 \mu \mathrm{M}\right)\end{array}$ & $\begin{array}{l}\text { Chen et al. } \\
\text { (2017) }\end{array}$ \\
\hline $\begin{array}{l}\text { Akebonoic } \\
\text { acid }\end{array}$ & $\begin{array}{l}\text { Cytotoxic } \\
\text { activities }\end{array}$ & $\begin{array}{l}\text { Cytotoxic effects against } \mathrm{A} 549, \mathrm{HeLa} \text {, HepG2 cancer cell lines with } \mathrm{IC}_{50} \text { values } \\
49.48,28.63 \text { and } 52.89 \mu \mathrm{M} \text {, respectively }\end{array}$ & $\begin{array}{l}\text { Wang et al. } \\
\text { (2014) }\end{array}$ \\
\hline
\end{tabular}

mulberrofuran K have not been investigated, however, enzyme kinetic studies on the structuraly similar Diels-Alder adduct yunanensin A showed a competitive mode of inhibition against alpha-glucosidase. Furthermore, molecular docking simulation showed that yunanensin A have higher hydrogen binding affinities to similar residues as acarbose (Ha et al. 2018).

\section{Other bioactivities}

In addition to inhibiting alpha-glucosidase, mulberrofuran $\mathrm{K}$ showed slightly weaker inhibitory activity against PTP1B $\left(\mathrm{IC}_{50}=8.49 \mu \mathrm{M}\right)$, an enzyme that plays a key role in the regulation of insulin signaling (Ha et al. 2018) highlighting the therapeutic importance of this molecule for the treatment of type 2 diabetes.
Anti-inflammatory activity of mulberrofuran $\mathrm{K}$ was also reported using lipopolysaccharide-induced RAW264.7 cells. Mulberrofuran K inhibited the production of proinflammatory mediators including NO, TNF- $\alpha$, IL-1 $\beta$, IL-6, and ROS in a dose dependent manner. Moreover, this compound suppressed the expression of inducible nitric oxide synthase and cyclooxygenase- 2 as well as the transcriptional activation of nuclear factor- $\kappa \mathrm{B}$ and extracellular-regulated kinases $1 / 2$ in murine macrophages (Shim et al. 2018). Mulberrofuran K also exhibited anti-Alzheimer's activity through the suppression of NO production $\left(\mathrm{IC}_{50}=7.1 \mu \mathrm{M}\right)$ and the inhibition of tau protein aggregation at a concentration of $20 \mu \mathrm{M}$ (Xia et al. 2019). The mechanism of action underlying the neuroprotective effect of mulberrofuran $\mathrm{K}$ involves the up-regulation of glutathione level and the inhibition of ROS generation $(0.5,1$, and $2 \mu \mathrm{M})$. Interestingly, this compound demonstrated the ability to cross 
the blood-brain barrier suggesting that mulberrofuran $\mathrm{K}$ had the potential to be a good neuroprotective agent.

\section{Pharmacokinetics and toxicity}

Pharmacokinetic studies on Morus Diels-Alder adducts are very limited and the pharmacokinetics properties of mulberrofuran $\mathrm{K}$ still need to be investigated. Available knowledge based on the study of kuwanon $\mathrm{G}$ include poor water-solubility and low GI absorption (Thu et al. 2020). However, the oral toxicity evaluation of ethanolic extract from Morus alba showed low toxicity even at a $2000 \mathrm{mg} / \mathrm{kg}$ dose (De Oliveira et al. 2015). The structuraly similar molecules mulberrofuran $\mathrm{G}$ and albanol $\mathrm{B}$ were nontoxic up to $5 \mu \mathrm{M}$ in HepG2 cells and toxicity increased at a concentration of $10 \mu \mathrm{M}$ (36\% and 73\% viable cell, respectively) (Paudel et al. 2018).

Overall results on mulberrofuran $\mathrm{K}$ and structuraly similar compounds showed the efficiency of this molecule in the management of type 2 diabetes through alpha-glucosidase and PTP1B inhibition. This molecule inhibited alpha-glucosidase at an $\mathrm{IC}_{50}$ value significantly lower than the toxic concentration reported for related compounds, and thus is expected to show lower toxicity when administered to the patients. However, preclinical and clinical studies on the pharmacological properties and safety of mulberrofuran $\mathrm{K}$ in animals and humans is still required.

Stilbenes

Stilbenes are an important class of naturally occurring polyphenols that possess 1,2-diphenylethylene on their core chemical structure (Sirerol et al. 2016). Stilbenes possess various biological properties such as anticancer, anti-diabetic and anti-inflammatory properties (Akinwumi et al. 2018).

\section{Alpha-glucosidase inhibition}

Most of the stilbene molecules covered in this review exhibited potent inhibitory activities against alphaglucosidase. The presence of more stilbene moieties positively contributed to the potency of the isolated compounds. For instance, the inhibitory activity of the stilbene tetramer (compound 170; online resource 1 and 2) $\left(\mathrm{IC}_{50}=13.57 \mu \mathrm{M}\right)$ was higher than the monomer (compound 171; online resource 1 and 2)
$\left(\mathrm{IC}_{50}=123.39 \mu \mathrm{M}\right)$. Morover, the trimers (compounds 176-178; online resource 1 and 2) exhibited an inhibitory activity higher than the dimers (compounds 172-175; online resource 1 and 2).

The highest inhibitory activity was observed with five stilbenes (compounds 179-182; online resource 1 and 2) isolated from the roots of Polygonum multiflorum (Yang et al. 2017). This plant has been widely used in traditional Chinese medicine for the prevention and therapy of various human diseases such as liver damage, cancer and diabetes (Bounda and Feng 2015). A rhaponticin isolated from the roots of Polygonum multiflorum showed the highest inhibitory activity against alpha-glucosidase enzyme $\left(\mathrm{IC}_{50-}\right.$ $=0.3 \mu \mathrm{M})$ in comparison to acarbose $\left(\mathrm{IC}_{50}\right.$ $=50.04 \mu \mathrm{M})($ Fig. 3; Table 2) (Yang et al. 2017).

\section{Other bioactivities}

Rhaponticin (3,3',5-trihydroxy-4'-methoxystilbene-3$O$-b-d-glucoside) is a bioactive stilbene compound found in the plant species of the genus Rheum. Several studies have shown that rhaponticin possess a wide range of biological activities such as anticancer, antioxidant and antithrombotic activities (Zhao et al. 2012). Along with its potent antidiabetic effect in vitro, rhaponticin $(125 \mathrm{mg} / \mathrm{kg})$ attenuated glucose levels, enhanced glucose tolerance and impeded hepatic fibrosis and steatosis in diabetic mice as well (Chen et al. 2009).

Up to $200 \mu \mathrm{M}$, rhaponticin also showed anti-cancer properties reflected in the induction of apoptosis in stomach cancer cells (Hibasami et al. 2007) and downregulation of the expression of FAS in breast cancer cells in a concentration-dependent manner and up to $400 \mu \mathrm{M}$ (Li et al. 2014) (Table 3). Moreover, rhaponticin showed inhibitory activity against lipoxygenase enzyme $\left(\mathrm{IC}_{50}=34.3 \mu \mathrm{M}\right)$, a key enzyme that involves in the production of pro-inflammatory mediators (Ngoc et al. 2008). Nevertheless, this molecule was significantly more potent against alpha-glucosidase.

Zhao et al. (2020) investigated the neuroprotective effect of rhaponticin in vitro and in vivo. This molecule suppressed the increased levels proinflammatory mediators including NO, $\mathrm{PGE}_{2}, \mathrm{TNF}-\alpha$, IL- $1 \beta$, IL-6, and reactive oxygen species (ROS) in lipopolysaccharide-induced microglial cells at noncytotoxic doses $(10,25$ and $50 \mu \mathrm{M})$. Furthermore, rhaponticin ameliorated motor impairments in MPTP- 
induced mice as well as prevented the damage of dopaminergic neurons (Misiti et al. 2006). The biochemical data obtained from in vitro and in vivo bioassays on rhaponticin provide a valuable indication of the importance of this molecule in drug discovery Rhaponticin showed particularly high selectivity and efficiency in inhibiting alpha-glucosidase at very low concentration compared to the other bioactivities exhibited by this molecule.

\section{Pharmacokinetics and toxicity}

The pharmacokinetic properties of rhaponticin were examined by different studies (Zhao et al. 2011; Sun et al. 2013, 2016). Rhaponticin pharmacokinetics was studied in vivo in rats after oral $(100 \mathrm{mg} / \mathrm{kg})$ and intravenous $(10 \mathrm{mg} / \mathrm{kg})$ administration. The molecule is rapidly metabolized and distributed in rats and its bioavailability was found to be very low $(0.03 \%)$. The oral administration of rhaponticin resulted in a lower concentration of its metabolite $(\mathrm{Cmax}=4.06 \mu \mathrm{M})$ than when injected intravenously $(\mathrm{Cmax}=21.2 \mu \mathrm{M})$. Interestingly, the $\mathrm{IC}_{50}$ value of rhaponticin for alphaglucosidase inhibition $\left(\mathrm{IC}_{50}=0.3 \mu \mathrm{M}\right)$ was significantly lower than its maximum serum concentrations. Moreover, the area under the curve (AUC $(0-t)$ ) for the oral and intravenous administration was found to be $0.70 \mu \mathrm{g} \mathrm{min} / \mathrm{ml}$ and $215.8 \mu \mathrm{g} \mathrm{min} / \mathrm{ml}$, respectively (Zhao et al. 2012). Rhaponticin showed no toxic effect when given up to $2000 \mathrm{mg} / \mathrm{kg}$ in adult male Wistar rats (Shi et al. 2020). To enhance the bioavailability of rhaponticin, Liang et al. (2013) utilized a folate receptor-targeted rhaponticin conjugate. This conjugate was synthesized by using a hydrophilic peptide spacer connected to folic acid through a releasable disulfide linker. Folic acid binds with high affinity to folate receptors, which are over-expressed in tumor cells and restricted in normal human cells. This conjugate significantly improved the therapeutic properties of rhaponticin as well as decreased the toxicity associated with this compound.

Rhaponticin is converted by the digestive enzymes and the intestinal microbial flora to rhapontigenin (Kim et al. 2000). This biotransformation is reflected by a rapid decrease in plasma levels of rhaponticin after the iv. dose (Tmax $=10 \mathrm{~min}$ ) and an increase in plasma concentrations of rhapontigenin $(\mathrm{Cmax}=0.18$ $\mu \mathrm{g} / \mathrm{ml}$ ) after $52 \mathrm{~min}$ (Zhao et al. 2012). Interestingly, this molecule displayed potent non-competitive yeast alpha-glucosidase inhibition $(80 \%$ inhibition at $19.4 \mu \mathrm{M})$ and the molecule was classified as weak, negative, homotropic, M-modulator (Babu et al. 2004). It is therefore important to emphasize that the low bioavailability of rhaponticin does not necessarily mean a reduced alpha-glucosidase inhibitory activity as this molecule is biotransformed to potent inhibitor following administration. However, rhapontigen showed toxic effect in murine macrophage cells after treatment for $18 \mathrm{~h}$ at a concentration of $10 \mu \mathrm{M}$ (Chong et al. 2021). Consequently, investigating the safety of this metabolite when rhaponticin is administered, as alpha-glucosidase inhibitor is essential.

\section{Tannins}

Tannins are structurally complex phenolic compounds that are categorized based on their chemical structure into two main groups, condensed and hydrolysable tannins. Hydrolysable tannins are derived from gallic acid, while condensed tannins result from the condensation of the phenolic compounds (Ghosh 2015).

\section{Alpha-glucosidase inhibition}

Several tannins from the fruits of Terminalia chebula (compounds 179-205; online resource 1 and 2) showed alpha-glucosidase inhibitory activity with $\mathrm{IC}_{50}$ values ranging between 2.9 and $68.4 \mu \mathrm{M}$ compared to $174 \mu \mathrm{M}$ for acarbose (Lee et al. 2017). The in vitro alpha-glucosidase inhibitory activity of procyanidins was previously reported to increase with the degree of polymerization of these compounds (Schäfer and Högger 2007), which is consistent with the reported results in this review. Procyanidins are naturally occurring condensed tannins that are made up of catechin and epicatechin molecules (Lee 2017). Based on the stereo configuration and the bonding between the monomers, procyanidins are classified into A and B types (Rue et al. 2018).

Procyanidin A2 (Fig. 3; Table 2), isolated from the shoots of Wendlandia glabrata, inhibited alpha-glucosidase enzyme with a remarkably low $\mathrm{IC}_{50}$ value of $0.47 \mu \mathrm{M}$ compared to $586.6 \mu \mathrm{M}$ for acarbose (Sheikh et al. 2019). It is an A-type dimeric form of procyanidin. The high inhibitory activity of procyanidin A2 was previously attributed to the unsaturated $\mathrm{C}$ ring, 3-OH, and hydroxyl substitutions on the $\mathrm{B}$ ring (Choi et al. 2017). Interestingly, the oral administration of 
structurally similar procyanidins did not inhibit intestinal $\alpha$-glucosidase activity in vivo (Yamashita et al. 2016). The poor correlation between in vitro and in vivo studies on these compounds highlights the importance of investigativing the anti-diabetic properties of procyanidin A2 in animal models and human clinical trials.

\section{Other bioactivities}

The protective effect of procyanidins against type 2 diabetes was previously investigated in mice and these molecules were found to improve glycemia and insulin sensitivity (Ogura et al. 2016). Procyanidins targeted glucose uptake and lipogenesis in insulinsensitive tissues (Del Bas et al. 2009), insulin secretion and production and $\beta$-cell mass in pancreatic cells (Ogura et al. 2016), and the regulation of the active glucagon-like peptide-1 (GLP-1) levels in the gut (González-Abuín et al. 2014). The procyanidin-induced increase of GLP-1 was found to be triggered by the inhibition of intestinal dipeptidyl-peptidase 4 activity (González-Abuín et al. 2014).

Additionaly, procyanidin A2 also exhibited other bioactivities including anti-inflammatory, anti-oxidative and antiviral activities (Xu et al. 2010; Wang et al. 2020, Table 3). This molecule inhibited the production of $\mathrm{C}-\mathrm{C}$ motif chemokine 11 that is induced by proinflammatory cytokines in lung epithelial cells at noncytotoxic doses up to $20 \mu \mathrm{M}$ (Coleman et al. 2016). In addition, procyanidin $\mathrm{A} 2$ exhibited neuroprotective effect through the inhibition of proinflammatory mediators and apoptosis in cell culture system. Moreover, this compound showed an inhibitory activity against severe acute respiratory syndrome coronavirus (SARS-CoV) infection with an $\mathrm{IC}_{50}$ value of $29.9 \mu \mathrm{M}$ (Zhuang et al. 2009).

Procyanidin A2 inhibited oxidative stress induced by tert-butyl hydroperoxide $(t-\mathrm{BOOH})$ in human fetal hepatocyte line (L-02) at non-cytotoxic doses up to $40 \mu \mathrm{M}$. The mechanism of action that underline the antioxidant activity of procyanidin A2 involves the inhibition of ROS generation and the inhibition of lactate dehydrogenase (LDH) production. Moreover, this compound exhibited a potent inhibitory activity against the oxidation of low-density lipoprotein (LDL) $\left(\mathrm{IC}_{50}=2.1 \mu \mathrm{M}\right)($ Park et al. 2014).

\section{Pharmacokinetics and toxicity}

Polyphenolic compounds including procyanidin A2 have been studied for pharmacokinetic properties in vivo in rats after oral administration of $250 \mathrm{mg} / \mathrm{kg}$ of peanut skin extract (PSE) (Bansode et al. 2014). Procyanidin A2, catechin and epicatechin were the major metabolities found in the rat plasma. The maximum concentration of procyanidin A2 was reached after $30 \mathrm{~min}$ of administration. Moreover, procyanidin A2 displayed a rapid clearance from plasma within $1 \mathrm{~h}$ after PSE intake. Interestingly, unlike, epicatechin, procyanidin dimers did not undergo conjugation or methylation in vivo which can help conserve their bioactivity in the intestine (Appeldoorn et al. 2009). In the context of using these molecules for the treatment of type 2 diabetes, the effect of carbohydrate-rich diet on the digestibility and bioavailability of procyanidins was also investigated (Serra et al. 2010). Dimeric and trimeric procyanidins showed high stability when exposed to gastric and intestinal digestions and very limited absorption in the small intestine. In addition, carbohydrates intake was found to enhance the uptake of procyanidin monomers. The encapsulation of procyanidin fractions from Leucosidea sericea in silver nanoparticles was found to further enhance the stability of these compounds without altering their inhibitory effect against alphaglucosidase and alpha-amylase enzymes (Badeggi et al. 2020). The stability of the nanoformulation of procyanidins is encouraging for the development of new alpha-glucosidase inhibitor as such drug needs to resist degradation by digestive juices and intereactions with intestinal microorganisms.

\section{Anthraquinones}

Anthraquinones are natural aromatic phenolic compounds characterized by the presence of 9,10-anthraquinone nucleus (Nguyen et al. 2018). A group of anthraquinones along with other types of molecules were isolated from the seeds of Cassia obtusifolia and evaluated for their alpha-glucosidase inhibitory activities (Jung et al. 2017). The seeds of Cassia obtusifolia have been used traditionally to treat different diseases including headache, ophthalmic diseases, and hypertension. This plant species is a rich source of bioactive anthraquinones such as emodin, alaternin, physcion and obtusifolin (Jung et al. 2016). 


\section{Alpha-glucosidase inhibition}

The methanolic extract of Cassia obtusifolia seeds previously showed similar $\alpha$-amylase $(79.80 \%) \alpha$ glucosidase (81.04\%) inhibitory effect as acarbose (Vadivel et al. 2012). The anthraquinones isolated from this plant and discussed in this review showed an overall weak inhibitory activity against alpha-glucosidase compared to acarbose (compounds 206-217; online resource 1 and 2) except for alaternin which was significantly more efficient $\left(\mathrm{IC}_{50}=3.45 \mu \mathrm{M}\right)$ (Fig. 3; Table 2; Jung et al. 2017). Alaternin acted as a mixed-type inhibitor against alpha-glucosidase enzyme with high affinity reflected by a $K i$ value of $0.66 \mu \mathrm{M}$. The higher inhibitory activity of alaternin was attributed to the presence of free hydroxy groups at the C-1, C-6, and C-8 positions (Jung et al. 2017). However, docking eperiments are still required to elucidate the mechanism of interaction.

\section{Other bioactivities}

In addition to the inhibition of alpha-glucosidase, alaternin was also found to play a role in enhancing insulin sensitivity by competitively inhibiting protein tyrosine phosphatase $1 \mathrm{~B}$ (PTP1B) with an $\mathrm{IC}_{50}$ value of $1.22 \mu \mathrm{M}$, slightly smaller than that reported with alpha-glucosidase (Table 3) (Jung et al. 2017). Molecular docking results revealed that the hydroxyl groups of this compound bind tightly with four residues at the active site of PTP1B with negative binding energy. The over-expression of PTP1B was associated with decreased insulin sensitivity in mice and the downregulation of insulin activity (Goldstein et al. 2000; Klaman et al. 2000). A therapeutic approach using alaternin as drug candidate that targets both, the reduction of postprandial hyperglycemia and the enhancement of insulin sensitivity can be therefore very promising for the management of type- 2 diabetes. Other reported bioactivities of alaternin include potent antioxidant ability against peroxynitrite with $\mathrm{IC}_{50}$ value of $2.70 \mu \mathrm{M}$ (Park et al. 2004), and hepatoprotective effects on tacrine-mediated cytotoxicity with $\mathrm{EC}_{50}$ value of $4.02 \mu \mathrm{M}$ (Jung et al. 2004). Alaternin $(10 \mathrm{mg} / \mathrm{kg})$ also showed neuroprotective effect in vivo in mice by inhibiting nitrotyrosine and lipid peroxidation, suppressing the expression of iNOS and decreasing microglial activation (an indicator of inflammation) (Shin et al. 2010).
Alaternin showed more potent inhibition against alpha-glucosidase compared to other enzymes such as tyrosinase $\left(\mathrm{IC}_{50}=327.3 \mu \mathrm{M}\right)(\mathrm{Lu}$ and $\mathrm{Ko} 2016)$ acetylcholinesterase $\left(\mathrm{IC}_{50}=21.9 \mu \mathrm{M}\right)$, and butyrylcholinesterase $\left(\mathrm{IC}_{50}=394.77 \mu \mathrm{M}\right)($ Jung et al. 2016). On the other hand, this molecule was highly efficient against beta-secretase $1\left(\mathrm{IC}_{50}=3.28 \mu \mathrm{M}\right)$ (Jung et al. 2016). Alaternin also inhibited monoamine oxidases $A$ and $\mathrm{B}$ (MAO) which are enzymes that catalyze the degradation of monoamine neurotransmitters (Yeung et al. 2019). Similar to alpha-glucosidase inhibition, the inhibition of MAO enzymes by alaternin followed a mixed-type inhibitory mechanism with $\mathrm{IC}_{50}$ values of 5.35 and $4.55 \mu \mathrm{M}$ for human MAO-A and B, respectively.

\section{Pharmacokinetics and toxicity}

Natural anthraquinones can either be found as aglycans or linked to sugar moiety, forming more polar molecules. Anthraquinones are usually found in plants as glycosides and the absorption of these molecules in the intestine involves the hydrolysis of anthraquinone glycosides to their respective aglycone forms. The absorbed molecules are further subjected to hepatic glucuronidation and eliminated through urine or bile (Mohammed et al. 2020). Although alaternin has been shown to have several pharmacological properties, there have been no studies that describe the pharmacokinetic properties of this compound. However, the bioavailability and absorption of other analogues (e.g. emodin, chrysophanol and physcion) were extensively studied (Shia et al. 2009; Wu et al. 2014a). These studies have shown the low bioavailability of the aforementioned molecules. For example, emodin have shown low bioavailability when administered orally in rats which can be attributed to its extensive in vivo glucuronidation (Shia et al. 2010). Consequently, the oral administration of these compounds is not optimal because of poor intestinal absorption and low bioavailability in vivo. Oral administration of anti-diabetic drugs presents several advantages including ease of production, stability of the formulation, ease of administration and patient compliance. New approaches need to be investigated to enhance the absorption and bioavailability of anthraquinones as anti-diabetic drugs.

The toxicity profile of alaternin was not extensively studied and this molecule did not show any cytotoxic 
effect on liver hepatocellular cells (HepG2) up to $50 \mu \mathrm{M}$ (Jung et al. 2017). However, in vitro and in vivo studies on structurally related emodin revealed a significant toxic effect on liver and kidney cells (Wang et al. 2007). At a concentration between 30 and $80 \mu \mathrm{M}$, emodin was found to induce apoptosis in human fetal hepatocytes ( $\mathrm{Li}$ et al. 2012) and human renal proximal tubule cells (Wang et al. 2015). Studies have demonstrated that emodin also exert reproductive toxicity by altering the expression of testicular genes (Oshida et al. 2011) and inhibiting human sperm functions (Luo et al. 2015). Accordingly, the toxicity of alaternin on different organs, particularly hepatotoxicity and nephrotoxicity after long-term exposure needs to be investigated.

\section{Coumarins}

Coumestans are polycyclic aromatic natural compounds characterized by the presence of coumestan moiety (Nehybova et al. 2014). Several coumestans (compounds 221-224; online resource 1 and 2) were isolated from the roots of Dolichos trilobus, an herbal plant used in the Chinese folk medicine to treat rheumatism and fracture.

\section{Alpha-glucosidase inhibition}

The isolated coumestans exhibited noteworthy inhibitory activity with $\mathrm{IC}_{50}$ values ranging from 3.5-32.2 $\mu \mathrm{M}$ compared to $163.6 \mu \mathrm{M}$ for acarbose with psoralidin being the most potent inhibitor (Fig. 3, Table 2) (Jiang et al. 2019). Psoralidin is a naturally occurring prenylated coumestrol extensively studied for its anti-cancer, anti-osteoporosis, anti-microbial and neuroprotective activites (reviewed in Tu et al. 2021). However, very few papers reported the alphaglucosidase inhibitory activity of this molecule (Oh et al. 2010; Wang et al. 2013; Jiang et al. 2019). Enzyme kinetic analysis has revealed that proralidin follows a noncompetitive mode of inhibition (Oh et al. 2010). Prenylated coumestans are considered as potent $\alpha$-glucosidase inhibitors with the prenylated types and prenylated positions having a strong effect on this activity. Prenylation at C-2 in the case of psoralidin offers the highest inhibitory activity (Tu et al. 2021) making this molecule a promising drug candidate.

\section{Other bioactivities}

Several pre-clinical studies validated that psoralidin possess a broad spectrum of biological activities including estrogenic (Liu et al. 2014), anti-osteoporosis (Zhai et al. 2017), anti-inflammatory (Yang et al. 2011) and anti-microbial activities (Khatune et al. 2004).

Psoralidin was found to be a potent agonist for estrogen receptors alpha $(\mathrm{ER} \alpha)$ and beta $(\mathrm{ER} \beta)$. It induced the transcriptional activition of both ER genes with $\mathrm{EC}_{50}$ value of $3.68 \mu \mathrm{M}$ and $6.88 \mu \mathrm{M}$, respectively, highlighting its potential usage as hormone replacement therapy for the relief of estrogen deficiency-related symptoms in postmenopausal women (Liu et al. 2014). This molecule has also shown osteoprotective effects in ovariectomized rats by inhibiting bone resorption and enhancing osteoblast proliferation and differentiation (Zhai et al. 2018).

Psoralidin has also shown promising results in combating breast, colon, prostate and liver cancer by activating oxidative stress, promoting DNA damage via NADPH oxidase 4 (NOX4)-mediated ROS production, decreasing the cell viability and inducing apoptosis (Ren et al. 2016) (Jin et al. 2016) (Bin et al. 2019) (Szliszka et al. 2011). Despite its broad activity, human clinical trials with psoralidin are scarce with only the effect of this molecule on dermatological conditions being previously investigated (Gopal et al. 2001).

\section{Pharmacokinetics and toxicity}

The pharmacokinetic study of psoralidin was conducted after intragastric administration of 20 and $40 \mathrm{mg} / \mathrm{kg}$ in rats. The half-life $\left(\mathrm{T}_{1 / 2}\right)$ was $7.2 \mathrm{~h}$ and $7.1 \mathrm{~h}, \mathrm{Cmax}$ was $0.0095 \mathrm{mg} / \mathrm{L}$ and $0.0263 \mathrm{mg} / \mathrm{L}$, and AUC was $0.0954 \mathrm{mg} / \mathrm{L} \mathrm{h}$ and $0.2 \mathrm{mg} / \mathrm{L} \mathrm{h}$ for different dosages, respectively. Moreover, psoralidin displayed a large volume of distribution $\left(\mathrm{V}_{\mathrm{d}}\right)$ (600.1 and 630.1 $\mathrm{L} / \mathrm{kg}$ for the 20 and $40 \mathrm{mg} / \mathrm{kg}$ dosages, respectively) (Feng et al. 2020). The intravenous administration of this molecule $(2 \mathrm{mg} / \mathrm{kg})$ in male Wister rats showed higher bioavailability with Cmax value of $2.19 \mathrm{mg} / \mathrm{L}$, AUC value of $1.95 \mathrm{mg} / \mathrm{L} . \mathrm{h}$ and half life of $4.45 \mathrm{~h}$ (Shi et al. 2016b). The volume of distribution following intravenous administration was also significantly smaller $(\mathrm{Vd}=6.22 \mathrm{~L} / \mathrm{kg})$. However, the development of new nanoencapsulated forms of psoralidin 
increased the efficacy of oral delivery (Yin et al. 2016).

CYP2C19 enzyme was found to be the main enzyme responsible for the metabolism of psoralidin and the process involves reduction and hydroxylation reactions in the prenyl group of $\mathrm{C}-2$ position. More importantly, psoralidin was found to exhibit potent inhibitory activity against CYP and UGT isoforms, which can result in drug-drug interactions and adverse effects (Shi et al. 2016b).

Although, psoralidin presented beneficial anti-diabetic and pharmacological activities, the pharmacodynamics behind its anti-diabetic effect are still to be investigated. Studies on long-term toxicity and possible interactions with other drugs are also required. Another limitation is the low oral bioavailability of this molecule due to its poor water solubility. New methods need to be developed to improve water solubility and bioavailability of psoralidin without affecting its alpha-glucosidase inhibitory activity.

\section{Conclusion}

The therapeutic intervention through targeting alphaglucosidase enzyme is a well-known strategy that was utilized for the treatment and management of type 2 diabetes. Acarbose, miglitol and voglibose being the only commercially available alpha-glucosidase inhibitors during the last three decades, necessitated the search for other novel and effective avenues with reduced toxicity. Plant-derived compounds represent a natural source of bioactive compounds that can be used for the development of effective drugs against diabetes mellitus. This review identified 8 chemically diverse plant molecules exhibiting potent alpha-glucosidase inhibitory activity compared to the positive controls (Taxumariene F, Akebonoic acid, Morusin, Rhaponticin, Procyanidin A2, Alaternin, Mulberrofuran $\mathrm{K}$ and Psoralidin) and can be considered as promising drug candidates for the treatment of type 2 diabetes.

The amount of information available on the selected compounds varied widely but previously studied molecules were all found to exhibit a wide range of biological activities. In addition to alphaglucosidase inhibition, interestingly four of the selected compounds (rhaponticin, procyanidins, alaternin and mulberrofuran $\mathrm{K}$ ) showed broader anti- diabetic activities that contributed to improved insulin signaling. Such molecules can be very promising in the development of a single drug resulting in shortened therapy and increased efficiency in controlling glycemia. However, more pre-clinical and clinical studies on these molecules are needed to determine their mechanisms of inhibition, pharmacokinetics and toxicology. Very few studies if any investigated the bioactivity of these molecules in vivo as well as the long-term toxicological assessment of these compounds. In addition, the pharmacokinetic properties of the promising compounds need to be investigated in the frame of their application as alpha-glucosidase inhibitors. For example, the carbohydrate composition of a meal can have a strong effect on gastric secretions and hepatic blood flow which diretly affects flavonoid absorption (Schramm et al. 2003). The stability of the selected compounds under gastro-intestinal conditions is therefore a key factor to be investigated. Plantderived molecules are also known to interfere with the absorption and metabolism of other pharmaceutical agents (Sprouse and van Breemen 2016). It is therefore important to investigate this aspect especially if the described molecules will be used as supplements for the enhancement of existing therapies.

Available infomartion showed overall poor bioavailability, low stability and rapid metabolism which has a negative impact on the efficiency of the natural compounds as future antidiabetic agents. However, the alpha-glucosidase inhibitors identified in this review are small molecules and their use as drugs has several advantages. The pharmacokinetics and pharmacodynamics of such molecules are more easily determined leading to optimal dosage and more understanding of potential side effect and drug-drug interactions. Small molecules can also be produced by chemical synthesis limiting variations in their composition. In addition, by chemical synthesis, the stability, solubility and bioavailability of the end drug can be improved.

The structural differences between the potent inhibitors identified in this review and acarbose elucidated different modes of inhibition and sites of interaction with the enzyme. The ability to bind to different regions of the enzyme other than the active site allows the noncompetitive or mixed inhibition of the enzyme by these phytochemicals compared to acarbose. This gives the identified phytochemicals a broader inhibitrion specificity and makes them less 
affected by increased substrate concentrations. However, the nature of interaction and the exact amino acid residues involved are still to be determined for most of the identified molecules.

By comparing the inhibitory potential of structurally similar compounds, the functional groups responsible for enhanced activity were also hightlighted. The hydroxyl hydrogen atoms of the inhibitor interact by hydrogen bonding with oxygen atoms of the surrounding amino acids ( $\mathrm{Lu}$ et al. 2020). The position and the number of hydroxyl groups was therefore found to determine the binding capacity and inhibitory potential of a molecule. As revealed in this review, the nature of this interaction broadens the range of molecules that can potentially inhibit alphaglucosidase. The identification of these groups and the comparison between the various enzyme-inhibitor structures will help determine the critical binding sites of the enzyme and can be promising for the design of semi-synthetic drugs with optimized functional features and improved inhibitory activity.

Collectively based on what was presented, promising plants and compounds described in this review could be lead drug candidates for the future design of novel compounds useful in the management or treatment of type- 2 diabetes.

Acknowledgements Authors are supported by a Khalifa University of Science and Technology grant award CIRA2018-35.

Availability of data and materials Data sharing not applicable to this article as no datasets were generated or analysed during the current study.

\section{Declarations}

Conflict of interest The authors have no conflicts of interest to declare that are relevant to the content of this article.

\section{References}

Abuelizz HA, Anouar EH, Ahmad R et al (2019) Triazoloquinazolines as a new class of potent $\alpha$-glucosidase inhibitors: in vitro evaluation and docking study. PLoS ONE 14:1-13

Agarwal S, Mohamed MS, Raveendran S et al (2018) Formulation, characterization and evaluation of morusin loaded niosomes for potentiation of anticancer therapy. Chem Sci $8: 32621-32636$
Alrefai H, Allababidi H, Levy S, Levy J (2002) The endocrine system in diabetes mellitus. Endocrine 18:105-119

Altemimi A, Lakhssassi N, Baharlouei A et al (2017) Phytochemicals: extraction, isolation, and identification of bioactive compounds from plant extracts. Plants 6:1-23

Aly SH, Elissawy AM, Eldahshan OA et al (2019) The pharmacology of the genus Sophora (Fabaceae): an updated review. Phytomedicine 64:1-23

Appeldoorn MM, Vincken JP, Gruppen H, Hollman PCH (2009) Procyanidin dimers A1, A2, and B2 are absorbed without conjugation or methylation from the small intestine of rats. J Nutr 139:1469-1473

Arrijal IMH, Ma'arif B, Suryadinata A (2018) Activity of ethyl acetate extract from Chrysophyllum cainito L. Leaves in decreasing blood sugar level in male wistar rats. J Islamic Pharm 3:31-38

Atkinson MA, Eisenbarth GS, Michels AW (2014) Type 1 diabetes. Lancet 383:69-82

Aziz KMA (2012) Management of type-1 and type-2 diabetes by insulin injections in diabetology clinics-a scientific research review. Recent Pat Endocr Metab Immune Drug Discov 6:148-170

Babu KS, Tiwari AK, Srinivas PV et al (2004) Yeast and mammalian $\alpha$-glucosidase inhibitory constituents from Himalayan rhubarb Rheum emodi Wall.ex Meisson. Bioorg Med Chem Lett 14:3841-3845

Badeggi UM, Badmus JA, Botha SS et al (2020) Biosynthesis, characterization, and biological activities of procyanidin capped silver nanoparticles. J Funct Biomater 11:1-20

Bansode RR, Randolph P, Ahmedna M et al (2014) Bioavailability of polyphenols from peanut skin extract associated with plasma lipid lowering function. Food Chem 148:24-29

Barrett ML, Udani JK (2011) A proprietary alpha-amylase inhibitor from white bean (Phaseolus vulgaris): a review of clinical studies on weight loss and glycemic control. Nutr J 10:1-10

Bergman ME, Davis B, Phillips MA (2019) Medically useful plant terpenoids: biosynthesis occurrence and mechanism of action. Molecules 24(21):3961. https://doi.org/10.3390/ molecules 24213961

Bhowmick A, Banu S (2017) Therapeutic targets of type 2 diabetes: an overview. MOJ Drug Des Develop Ther 1:60-64

Bian G, Yang J, Elango J, Wu W, Bao B, Bao C (2021) Natural triterpenoids isolated from Akebia trifoliata stem explants exert a hypoglycemic effect via $\alpha$-Glucosidase inhibition and glucose uptake stimulation in insulin-resistant HepG2 cells. Chem Biodivers 18(5):e2001030. https://doi.org/10. 1002/cbdv.202001030

Bin Y, An-hong W, Kun Z et al (2019) Molecular pathway of psoralidin-induced apoptosis in HepG2 cell line. Chin J Integr Med 25:757-762

Bischoff H (1995) The mechanism of alpha-glucosidase inhibition in the management of diabetes. Clin Invest Med 18:303-311

Bounda GA, Feng Y (2015) Review of clinical studies of Polygonum multiflorum Thunb. and its isolated bioactive compounds. Pharmacogn Res 7:225-236

Bouriche H, Kada S, Assaf AM et al (2016) Phytochemical screening and anti-inflammatory properties of Algerian 
Hertia cheirifolia methanol extract. Pharm Biol 54:2584-2590

Cao F, Gao Y, Wang M, Fang L, Ping Q (2013) Propylene glycol-linked amino acid/dipeptide diester prodrugs of oleanolic acid for PepT1-mediated transport: synthesis intestinal permeability and pharmacokinetics. Mol Pharm 10(4):1378-1387. https://doi.org/10.1021/mp300647m

Chatterjee S, Davies MJ (2015) Current management of diabetes mellitus and future directions in care. Postgrad Med J 91:612-621

Chen J, Ma M, Lu Y et al (2009) Rhaponticin from rhubarb rhizomes alleviates liver steatosis and improves blood glucose and lipid profiles in KK/Ay diabetic mice. Planta Med 75:472-477

Chen CH, Hwang TL, Chen LC et al (2017) Isoflavones and anti-inflammatory constituents from the fruits of Psoralea corylifolia. Phytochemistry 143:186-193

Chen K, Liu XQ, Wang WL et al (2020) Taxumarienes A-G, seven new $\alpha$-glucosidase inhibitory taxane-diterpenoids from the leaves of Taxus mairei. Bioorg Chem 94:1-8

Choi SA, Lee JE, Kyung MJ et al (2017) Anti-diabetic functional food with wasted litchi seed and standard of quality control. Appl Biol Chem 60:197-204

Chong Y, Lee HL, Song J et al (2021) Biosynthesis of resveratrol derivatives and evaluation of their anti-inflammatory activity. Appl Biol Chem 64:1-10

Coleman SL, Hurst RD, Sawyer GM, Kruger MC (2016) The in vitro evaluation of isolated procyanidins as modulators of cytokine-induced eotaxin production in human alveolar epithelial cells. J Berry Res 6:115-124

Čulenová M, Sychrová A, Hassan STS et al (2020) Multiple In vitro biological effects of phenolic compounds from Morus alba root bark. J Ethnopharmacol 248:112296

Dai S-J, Wu Y, Wang Y-H et al (2004) New Diels-Alder type adducts from Morus macroura and their anti-oxidant activities. Chem Pharm Bull 52:1190-1193

Dang PH, Nguyen HX, Duong TTT et al (2017) $\alpha$-Glucosidase inhibitory and cytotoxic taxane diterpenoids from the stem bark of Taxus wallichiana. J Nat Prod 80:1087-1095

De Oliveira AMA, Mesquita MDS, Da Silva GC et al (2015) Evaluation of toxicity and antimicrobial activity of an ethanolic extract from leaves of Morus alba L. (Moraceae). Evid Based Complement Alternat Med 2015:1-7

de Zeeuw D, Akizawa T, Audhya P et al (2013) Bardoxolone methyl in type 2 diabetes and stage 4 chronic kidney disease. N Engl J Med 369:2492-2503

Del Bas JM, Ricketts ML, Vaqué M et al (2009) Dietary procyanidins enhance transcriptional activity of bile acid-activated FXR in vitro and reduce triglyceridemia in vivo in a FXR-dependent manner. Mol Nutr Food Res 53:805-814

des Gachons CP, Breslin PAS (2016) Salivary amylase: Digestion and metabolic syndrome. Curr Diab Rep 16:1-7

Doan HV, Riyajan S, Iyara R, Chudapongse N (2018) Antidiabetic activity, glucose uptake stimulation and $\alpha$-glucosidase inhibitory effect of Chrysophyllum cainito L. stem bark extract. BMC Complement Altern Med 18:1-10

Dyer J, Wood IS, Palejwala A et al (2002) Expression of monosaccharide transporters in intestine of diabetic humans. Am J Physiol Gastrointest Liver Physiol 282:G241-G248
Ernawati T, Mun'im A, Hanafi M, Yanuar A (2018) In silico evaluation of molecular interactions between known $\alpha$ glucosidase inhibitors and homologous $\alpha$-glucosidase enzymes from Saccharomyces cerevisiae, Rattus norvegicus, and GANC-human. Thai J Pharm Sci 42:14-20

Etsassala NGER, Badmus JA, Waryo TT, Marnewick JL, Cupido CN, Hussein AA, Iwuoha EI (2019) Alpha-Glucosidase and Alpha-Amylase Inhibitory Activities of Novel Abietane Diterpenes from Salvia africana-lutea. Antioxidants 8(10):421. https://doi.org/10.3390/ antiox 8100421

Fan W (2017) Epidemiology in diabetes mellitus and cardiovascular disease. Cardiovasc Endocrinol 6:8-16

Feng F, Jiang X, Qiu J et al (2020) Development of an UPLCMS/MS assay to determine psoralidin in rat plasma and its application in a pharmacokinetic study after intragastric administration. Acta Chromatogr 32:215-218

Flores JP, Saif MW (2013) Novel oral taxane therapies: recent Phase I results. Clin Invest 3:333-341

Ganesan S, Natesan SK (2017) Antidiabetic and antihyperlipidaemic activities of ensete superbum fractions on high fat fed with low dose streptozotocin induced type-2 diabetes in rats. Int J Chem Pharm Anal 4:1-14

Ghani U (2015) Re-exploring promising $\alpha$-glucosidase inhibitors for potential development into oral anti-diabetic drugs: finding needle in the haystack. Eur $\mathrm{J}$ Med Chem 103:133-162

Ghosh D (2015) Tannins from foods to combat diseases. Int J Pharm Sci Res Rev 4:40-44

Goldstein BJ, Bittner-Kowalczyk A, White MF, Harbeck M (2000) Tyrosine dephosphorylation and deactivation of insulin receptor substrate-1 by protein-tyrosine phosphatase 1B. J Biol Chem 275:4283-4289

González-Abuín N, Martínez-Micaelo N, Margalef M et al (2014) A grape seed extract increases active glucagon-like peptide-1 levels after an oral glucose load in rats. Food Funct 5:2357-2364

Gopal M, Farahana B, Kulkarni K (2001) Effectiveness of herbal medications in the treatment of acne vulgaris-a pilot study. Indian Pract 54:723

Gupta G, Dua K, Kazmi I, Anwar F (2014) Anticonvulsant activity of Morusin isolated from Morus alba: Modulation of GABA receptor. Biomed Aging Pathol 4:29-32

Ha MT, Hui S, Dat T et al (2018) Chalcone derivatives from the root bark of Morus alba L. act as inhibitors of PTP1B and a-glucosidase. Phytochemistry 155:114-125

Habtemariam S, Varghese GK (2017) Antioxidant, anti-alphaglucosidase and pancreatic beta-cell protective effects of methanolic extract of Ensete superbum Cheesm seeds. Asian Pac J Trop Biomed 7:121-125

Hai P, Wen S-Z, Li Y, Gao Y, Jiang X-J, Wang F (2014) New taxane diterpenoids from taxus yunnanensis. Nat Prod Bioprospecting 4(1):47-51. https://doi.org/10.1007/ s13659-014-0003-9

Hao D-C, Ge G-B, Wang P, Yang L (2018) Impact of drug metabolism/pharmacokinetics and their relevance upon Taxus-based drug development. Curr Drug Metab 19:930-959

Hedrington MS, Davis SN (2019) Considerations when using alpha-glucosidase inhibitors in the treatment of type 2 diabetes. Expert Opin Pharmacother 20:2229-2235 
Heinrich M (2013) Ethnopharmacology and drug discovery. Elsevier Ref Module Chem Mol Sci Chem Eng 3:351-381

Hibasami H, Takagi K, Ishii T et al (2007) Induction of apoptosis by rhapontin having stilbene moiety, a component of rhubarb (Rheum officinale Baillon) in human stomach cancer KATO III cells. Oncol Rep 18:347-351

Hou C, Liu W, Liang Z et al (2018) UGT-mediated metabolism plays a dominant role in the pharmacokinetic behavior and the disposition of morusin in vivo and in vitro. $\mathrm{J}$ Pharm Biomed Anal 154:339-353

Hu J, You F, Yang S, Li Y (2014) Quantitative determination of Lx2-32c, a novel taxane derivative, in rat plasma by liquid chromatography-tandem mass spectrometry. J Pharm Biomed Anal 88:483-488

Ibrahim A, Umar IA, Aimola IA, Mohammed A (2019) Inhibition of key enzymes linked to diabetes by Annona senegalensis Pers (Annonaceae) leaf in vitro. J Herb Med 16:1-6

Jeong DW, Kim YH, Kim HH et al (2007) Dose-Linear pharmacokinetics of oleanolic acid after intravenous and oral administration in rats. Biopharm Drug Dispos 28:51-57

Jiang MY, Luo M, Tian K et al (2019) $\alpha$-glucosidase inhibitory and anti-inflammatory coumestans from the roots of Dolichos trilobus. Planta Med 85:112-117

Jin Z, Yan W, Jin H et al (2016) Differential effect of psoralidin in enhancing apoptosis of colon cancer cells via nuclear factor- $\kappa \mathrm{B}$ and B-cell lymphoma-2/B-cell lymphoma-2-associated $\mathrm{X}$ protein signaling pathways. Oncol Lett 11:267-272

Jongkees SAK, Withers SG (2014) Unusual enzymatic glycoside cleavage mechanisms. Acc Chem Res 47:226-235

Jung HA, Hae YC, Yokozawa T et al (2004) Alaternin and emodin with hydroxyl radical inhibitory and/or scavenging activities and hepatoprotective activity on tacrine-induced cytotoxicity in HepG2 cells. Arch Pharm Res 27:947-953

Jung HA, Ali MY, Jung HJ, Jeong HO, Chung HY, Choi JS (2016) Inhibitory activities of major anthraquinones and other constituents from Cassia obtusifolia against $\beta$-secretase and cholinesterases. $\mathrm{J}$ Ethnopharmacol 191:152-160. https://doi.org/10.1016/j.jep.2016.06.037

Jung HA, Ali MY, Choi JS (2017) Promising inhibitory effects of anthraquinones, naphthopyrone, and naphthalene glycosides, from Cassia obtusifolia on $\alpha$-glucosidase and human protein tyrosine phosphatases 1B. Molecules 22:1-15

Khatune NA, Islam ME, Haque ME et al (2004) Antibacterial compounds from the seeds of $<\mathrm{i}>$ Psoralea corylifolia $<\mathrm{i} />$. Fitoterapia 75:228-230

Kim D-H, Park E-K, Bae E-A, Han MJ (2000) Metabolism of rhaponticin and chrysophanol 8-O-glucopyranoside from the rhizome of Rheum undulatum by humam intestinal bacteria and their anti-allergic actions. Biol Pharm Bull 23:830-833

Kim JY, Lee WS, Kim YS et al (2011) Isolation of cholinesterase-inhibiting flavonoids from Morus lhou. J Agric Food Chem 59:4589-4596

Klaman LD, Boss O, Peroni OD et al (2000) Increased energy expenditure, decreased adiposity, and tissue-specific insulin sensitivity in protein-tyrosine phosphatase 1B-deficient mice. Mol Cell Biol 20:5479-5489
Kunle OF, Egharevba HO, Ahmadu PO (2012) Standardization of herbal medicines-a review. Int J Biodvers Conserv 4:101-112

Lee Y (2017) Cancer chemopreventive potential of procyanidin. Toxicol Res 33:273-282

Lee JC, Won SJ, Chao CL et al (2008) Morusin induces apoptosis and suppresses NF- $\kappa \mathrm{B}$ activity in human colorectal cancer HT-29 cells. Biochem Biophys Res Commun 372:236-242

Lee DY, Kim HW, Yang H, Sung SH (2017) Hydrolyzable tannins from the fruits of Terminalia chebula Retz and their $\alpha$-glucosidase inhibitory activities. Phytochemistry 137:109-116. https://doi.org/10.1016/j.phytochem.2017. 02.006

Li CL, Ma J, Zheng L et al (2012) Determination of emodin in L-02 cells and cell culture media with liquid chromatography-mass spectrometry: application to a cellular toxicokinetic study. J Pharm Biomed Anal 71:71-78

Li P, Tian W, Wang X, Ma X (2014) Inhibitory effect of desoxyrhaponticin and rhaponticin, two natural stilbene glycosides from the Tibetan nutritional food Rheum tanguticum Maxim. ex Balf., on fatty acid synthase and human breast cancer cells. Food Funct 5:251-256

Li M, Wu X, Wang X et al (2018) Two novel compounds from the root bark of Morus alba L. Nat Prod Res 32:36-42

Liang X, Sun Y, Zeng W et al (2013) Synthesis and biological evaluation of a folate-targeted rhaponticin conjugate. Bioorg Med Chem 21:178-185

Lim S, lyul, Park S yoon, Kang S, et al (2015) Morusin induces cell death through inactivating STAT3 signaling in prostate cancer cells. Am J Cancer Res 5:289-299

Liu X, Nam JW, Song YS et al (2014) Psoralidin, a coumestan analogue, as a novel potent estrogen receptor signaling molecule isolated from Psoralea corylifolia. Bioorganic Med Chem Lett 24:1403-1406

Lombard V, Golaconda Ramulu H, Drula E et al (2014) The carbohydrate-active enzymes database (CAZy) in 2013. Nucleic Acids Res 42:D490-D495

Lu TM, Ko HH (2016) A new anthraquinone glycoside from Rhamnus nakaharai and anti-tyrosinase effect of 6-methoxysorigenin. Nat Prod Res 30:2655-2661

Lu H, Qi Y, Zhao Y, Jin N (2020) Effects of hydroxyl group on the interaction of carboxylated flavonoid derivatives with S. Cerevisiae $\alpha$-glucosidase. Curr Comput Aided Drug Des 16:31-44

Luo H, Wang LF, Imoto T, Hiji Y (2001) Inhibitory effect and mechanism of acarbose combined with gymnemic acid on maltose absorption in rat intestine. World J Gastroenterol 7:9-15

Luo T, Li N, He Y et al (2015) Emodin inhibits human sperm functions by reducing sperm $[\mathrm{Ca} 2+] \mathrm{i}$ and tyrosine phosphorylation. Reprod Toxicol 51:41-21

Ma X, Zheng C, Hu C et al (2011) The genus Desmodium (Fabaceae)-traditional uses in Chinese medicine, phytochemistry and pharmacology. J Ethnopharmacol 138:314-332

Mahajan M, Kaur Khurana R, Shri Sahajpal N, Utreja P, Sankar R, Singh B, Kumar Jain S (2015) Emerging strategies and challenges for controlled delivery of taxanes: a comprehensive review. Curr Drug Metab 16:453-473 
Majouli K, Mahjoub MA, Rahim F et al (2017) Biological properties of Hertia cheirifolia $\mathrm{L}$. flower extracts and effect of the nopol on $\alpha$-glucosidase. Int $\mathrm{J}$ Biol Macromol 95:757-761

Mandel AL, Breslin PAS (2012) High endogenous salivary amylase activity is associated with improved glycemic homeostasis following starch ingestion in adults. J Nutr 142:853-858

Mandrone M, Scognamiglio M, Fiorentino A et al (2017) Phytochemical profile and $\alpha$-glucosidase inhibitory activity of Sardinian Hypericum scruglii and Hypericum hircinum. Fitoterapia 120:184-193

Mao QQ, Xu XY, Cao SY et al (2019) Bioactive compounds and bioactivities of ginger (zingiber officinale roscoe). Foods $8: 1-21$

Misiti F, Sampaolese B, Mezzogori D et al (2006) Protective effect of rhubarb derivatives on amyloid beta (1-42) peptide-induced apoptosis in IMR-32 cells: a case of nutrigenomic. Brain Res Bull 71:29-36

Modak M, Dixit P, Londhe J et al (2007) Indian herbs and herbal drugs used for the treatment of diabetes. J Clin Biochem Nutr 40:163-173

Mohammed A, Ibrahim MA, Tajuddeen N et al (2020) Antidiabetic potential of anthraquinones: a review. Phytother Res 34:486-504

Murugan K, Shanmugasamy S, Al-Sohaibani S et al (2015) TaxKB: a knowledge base for new taxane-related drug discovery. BioData Min 8:1-9

Ndrianingsih AW, Tachibana S, Itoh K (2015) In vitro evaluation of antioxidant and $\alpha$-Glucosidase inhibitory assay of several tropical and subtropical plants. Procedia Environ Sci 28:639-648

Nehybova T, Smarda J, Benes P (2014) Plant coumestans: recent advances and future perspectives in cancer therapy. Anticancer Agents Med Chem 14:1351-1362

Ngoc TM, Minh PTH, Hung TM et al (2008) Lipoxygenase inhibitory constituents from rhubarb. Arch Pharm Res 31:598-605

Nguyen T, Pandey R, Parajuli P, Han J, Jung H, Park Y, Sohng J (2018) Microbial synthesis of non-natural anthraquinone glucosides displaying superior antiproliferative properties. Molecules 23(9):2171. https://doi.org/10.3390/ molecules23092171

Nguyen NH, Pham QT, Luong TNH et al (2020) Potential antidiabetic activity of extracts and isolated compound from Adenosma bracteosum (Bonati). Biomolecules $10: 1-12$

Ogura K, Ogura M, Shoji T et al (2016) Oral administration of apple procyanidins ameliorates insulin resistance via suppression of pro-inflammatory cytokine expression in liver of diabetic ob/ob Mice. J Agric Food Chem 64:8857-8865

Oh KY, Lee JH, Curtis-Long MJ et al (2010) Glycosidase inhibitory phenolic compounds from the seed of Psoralea corylifolia. Food Chem 121:940-945

García-Gómez E, Pérez-Badia R, Pereira J, Puri RK (2017) The consumption of acorns (from Quercus spp.) in the central west of the Iberian Peninsula in the 20th Century. Econ Bot 71:256-268

Onwusonye JC, Uwakwe AA, Iwuanyanwu P, Iheagwam U (2014) Oral acute toxicity (LD50) study of methanol extract of Annona senegalensis leaf in albino mice. Sky J Biochem Res 3:46-48

Ormazabal V, Nair S, Elfeky O et al (2018) Association between insulin resistance and the development of cardiovascular disease. Cardiovasc Diabetol 17:1-14

Oshida K, Hirakata M, Maeda A et al (2011) Toxicological effect of emodin in mouse testicular gene expression profile. J Appl Toxicol 31:790-800

Ouyang JK, Dong LM, Xu QL et al (2018) Triterpenoids with $\alpha$ glucosidase inhibitory activity and cytotoxic activity from the leaves of Akebia trifoliata. Chem Sci 8:40483-40489

Park TH, Kim DH, Kim CH et al (2004) Peroxynitrite scavenging mode of alaternin isolated from Cassia tora. J Pharm Pharmacol 56:1315-1321

Park HJ, Kim SY, Song NY et al (2014) Procyanidins from the stem wood of Machilus japonica and their inhibitory effect on LDL oxidation. Arch Pharm Res 37:1403-1410

Paudel P, Yu T, Seong SH et al (2018) Protein tyrosine phosphatase $1 \mathrm{~B}$ inhibition and glucose uptake potentials of mulberrofuran $\mathrm{G}$, albanol $\mathrm{B}$, and kuwanon $\mathrm{G}$ from root bark of Morus alba L. in insulin-resistant HepG2 cells: an in vitro and in silico study. Int J Mol Sci 19:1-18

Paudel P, Seong SH, Shrestha S et al (2019) In vitro and in silico human monoamine oxidase inhibitory potential of anthraquinones, naphthopyrones, and naphthalenic lactones from Cassia obtusifolia Linn seeds. ACS Omega 4:16139-16152

Rasoanaivo P, Wright CW, Willcox ML, Gilbert B (2011) Whole plant extracts versus single compounds for the treatment of malaria: Synergy and positive interactions. Malar J 10:1-12

Ren G, Luo W, Sun W et al (2016) Psoralidin induced reactive oxygen species (ROS)-dependent DNA damage and protective autophagy mediated by NOX4 in breast cancer cells. Phytomedicine 23:939-947

Rizvi TS, Hussain I, Ali L, Mabood F, Khan AL, Shujah S, Rehman NU, Al-Harrasi A, Hussain J, Khan A, Halim SA (2019) New gorgonane sesquiterpenoid from Teucrium mascatense Boiss as $\alpha$-glucosidase inhibitor. South Afr J Bot 124:218-222. https://doi.org/10.1016/j.sajb.2019.05. 008

Rosak C, Mertes G (2012) Critical evaluation of the role of acarbose in the treatment of diabetes: patient considerations. Diabetes Metab Syndr Obes 5:357-367

Rue EA, Rush MD, van Breemen RB (2018) Procyanidins: a comprehensive review encompassing structure elucidation via mass spectrometry. Phytochem Rev 17:1-16

Saeedi P, Petersohn I, Salpea P et al (2019) Global and regional diabetes prevalence estimates for 2019 and projections for 2030 and 2045: Results from the International Diabetes Federation Diabetes Atlas, 9th edition. Diabetes Res Clin 157:1-10

Sahoo AK, Dash UC, Kanhar S, Mahapatra AK (2017) In vitro biological assessment of Homalium zeylanicum and isolation of lucidenic acid A triterpenoid. Toxicol Rep 4:274-281

Sánchez-González M, Colom H, Lozano-Mena G et al (2014) Population pharmacokinetics of maslinic acid, a triterpene from olives, after intravenous and oral administration in rats. Mol Nutr Food Res 58:1970-1979 
Santos FA, Frota JT, Arruda BR et al (2012) Antihyperglycemic and hypolipidemic effects of $\alpha, \beta$-amyrin, a triterpenoid mixture from Protium heptaphyllum in mice. Lipids Health Dis $11: 1-8$

Santos CMM, Freitas M, Fernandes E (2018) A comprehensive review on xanthone derivatives as $\alpha$-glucosidase inhibitors. Eur J Med Chem 157:1460-1479

Sayed DF, Nada AS, Mohamed MAEH, Ibrahim MT (2019) Modulatory effects of Chrysophyllum cainito L. extract on gamma radiation induced oxidative stress in rats. Biomed Pharmacother 111:613-623

Schäfer A, Högger P (2007) Oligomeric procyanidins of French maritime pine bark extract (Pycnogenol ${ }^{\circledR}$ ) effectively inhibit $\alpha$-glucosidase. Diabetes Res Clin Pract 77:41-46. https://doi.org/10.1016/j.diabres.2006.10.011

Schramm DD, Karim M, Schrader HR et al (2003) Food effects on the absorption and pharmacokinetics of cocoa flavanols. Life Sci 73:857-869

Sedighiyan M, Abdolahi M, Taheri E et al (2018) The french maritime pine bark extract reduce metabolic syndrome risk and improve body composition in obesity: a new clinical approach. Acta Med Iranica 56:196-203

Seo DY, Lee SR, Heo JW et al (2018) Ursolic acid in health and disease. Korean J Physiol Pharmacol 22:235-248

Serra A, MacI A, Romero MP et al (2010) Bioavailability of procyanidin dimers and trimers and matrix food effects in in vitro and in vivo models. Br J Nutr 103:944-952

Sethiya NK, Shekh MR, Singh PK (2019) Wild banana [Ensete superbum (Roxb.) Cheesman.]: ethnomedicinal, phytochemical and pharmacological overview. J Ethnopharmacol 233:218-233

Shailajan S, Gurjar D (2014) Pharmacognostic and phytochemical evaluation of Chrysophyllum Cainito Linn. leaves. Int J Pharm Sci Rev Res 26:106-111

Shankar Naik B (2019) Developments in taxol production through endophytic fungal biotechnology: a review. Orient Pharm Exp Med 19:1-13

Sheikh Y, Chanu MB, Mondal G et al (2019) Procyanidin A2, an anti-diabetic condensed tannin extracted from Wendlandia glabrata, reduces elevated G-6-Pase and mRNA levels in diabetic mice and increases glucose uptake in CC1 hepatocytes and $\mathrm{C} 1 \mathrm{C} 12$ myoblast cells. Chem Sci 9:17211-17219

Shi X, Yang S, Zhang G et al (2016a) The different metabolism of morusin in various species and its potent inhibition against UDP-glucuronosyltransferase (UGT) and cytochrome p450 (CYP450) enzymes. Xenobiotica 46:467-476

Shi X, Zhang G, Mackie B et al (2016b) Comparison of the in vitro metabolism of psoralidin among different species and characterization of its inhibitory effect against UDPglucuronosyltransferase (UGT) or cytochrome p450 (CYP450) enzymes. J ChromatogrB 1029-1030:145-156

Shi Q, Cheng Y, Dong X et al (2020) Effects of rhaponticin on retinal oxidative stress and inflammation in diabetes through NRF2/HO-1/NF- $\kappa \mathrm{B}$ signalling. J Biochem Mol Toxicol 34:1-9

Shia CS, Juang SH, Tsai SY et al (2009) Metabolism and pharmacokinetics of anthraquinones in rheum palmatum in rats and ex vivo antioxidant activity. Planta Med 75:1386-1392
Shia C-S, Hou Y-C, Tsai S-Y et al (2010) Differences in pharmacokinetics and ex vivo antioxidant activity following intravenous and oral administrations of emodin to rats. J Pharm Sci 99:2185-2195

Shim SY, Sung SH, Lee M (2018) Anti-inflammatory activity of mulberrofuran $\mathrm{K}$ isolated from the bark of Morus bombycis. Int Immunopharmacol 58:117-124

Shin BY, Kim DH, Hyun SK et al (2010) Alaternin attenuates delayed neuronal cell death induced by transient cerebral hypoperfusion in mice. Food Chem Toxicol 48:1528-1536

Simmons KM, Michels AW (2015) Type 1 diabetes: A predictable disease. World J Diabetes 6:380-390

Singla AK, Garg A, Aggarwal D (2002) Paclitaxel and its formulations. Int J Pharm 235(1-2):179-192. https://doi.org/ 10.1016/S0378-5173(01)00986-3

Sirerol JA, Rodríguez ML, Mena S, Asensi MA, Estrela JM, Ortega AL (2016) Role of natural stilbenes in the prevention of cancer. Oxid Med Cell Longev 2016:3128951. https://doi.org/10.1155/2016/3128951

Snehlata K, Sheel R, Kumar B (2018) Evaluation of phytochemicals in polar and non polar solvent extracts of leaves of Aegle marmelos (L.). IOSR j Biotechnol Biochem 4:31-38

Sprouse AA, van Breemen RB (2016) Pharmacokinetic interactions between drugs and botanical dietary supplements. Drug Metab Dispos 44(2):162-171. https://doi.org/10. 1124/dmd.115.066902

Sun Y, Zhao Y, Yang X (2013) A simple and rapid spectrofluorimetric method for determining the pharmacokinetics and metabolism of rhaponticin in rat plasma, feces and urine using a cerium probe. Luminescence 28:523-529

Sun Y, Wang W, Cheng H et al (2016) Study of the binding and energy transfer of erbium ion with rhaponticin and its pharmacokinetics application. Luminescence 31:1251-1258

Szliszka E, Czuba ZP, Sȩdek Ł et al (2011) Enhanced TRAILmediated apoptosis in prostate cancer cells by the bioactive compounds neobavaisoflavone and psoralidin isolated from $<\mathrm{i}>$ Psoralea corylifolia $<\mathrm{i} />$. Pharmacol Rep 63:139-148

Tabopda TK, Ngoupayo J, Awoussong PK et al (2008) Triprenylated flavonoids from Dorstenia psilurus and their $\alpha$-glucosidase inhibition properties. J Nat Prod 71:2068-2072

Tan K, Tesar C, Wilton R et al (2018) Interaction of antidiabetic $\alpha$-glucosidase inhibitors and gut bacteria $\alpha$-glucosidase. Protein Sci 27:1498-1508

Tang Y, Xiong R, Wu AG et al (2018) Polyphenols derived from lychee seed suppress $A \beta$ (1-42)-induced neuroinflammation. Int J Mol Sci 19:1-18

Thu HN, My LHT, Van PN, Do TH (2020) Bioactivity-guided Isolation and Identification of Xanthine Oxidase Inhibitors from Morus alba Bark. J Adv Pharm Res 4:94-100

Tripathi BK, Srivastava AK (2006) Diabetes mellitus: Complications and therapeutics. Med Sci Monit 12:RA130RA147

Tu Y, Yang Y, Li Y, He C (2021) Naturally occurring coumestans from plants, their biological activities and therapeutic effects on human diseases. Pharmacol Res 169:105615 
Tuan M, Hui S, Dat T et al (2018) Chalcone derivatives from the root bark of Morus alba L. act as inhibitors of PTP1B and $\alpha$ -glucosidase. Phytochemistry 155:114-125

Vadivel V, Kunyanga CN, Biesalski HK (2012) Antioxidant potential and type II diabetes-related enzyme inhibition of Cassia obtusifolia L.: effect of indigenous processing methods. Food Bioprocess Technol 5:2687-2696

Valls RM, Llauradó E, Fernández-Castillejo S et al (2016) Effects of low molecular weight procyanidin rich extract from french maritime pine bark on cardiovascular disease risk factors in stage-1 hypertensive subjects: Randomized, double-blind, crossover, placebo-controlled intervention trial. Phytomedicine 23:1451-1461

Vochyánova Z, Pokorna M, Rotrekl D et al (2017) Prenylated flavonoid morusin protects against TNBS-induced colitis in rats. PLoS ONE 12:1-14

Wan LZ, Ma B, Zhang YQ (2014) Preparation of morusin from Ramulus mori and its effects on mice with transplanted H22 hepatocarcinoma. BioFactors 40:636-645

Wang O, Wu C, Liao YM (2007) Study on the toxicity and its mechanisms of rhubarb and its major constituents. J Toxicol 21:301-302

Wang TX, Yin ZH, Zhang W et al (2013) Chemical constituents from Psoralea corylifolia and their antioxidant alpha-glucosidase inhibitory and antimicrobial activities. China $\mathbf{J}$ Chin Materia Med 38:2328-2333

Wang J, Xu QL, Zheng MF et al (2014) Bioactive 30-noroleanane triterpenes from the pericarps of Akebia trifoliata. Mol 19:4301-4312

Wang C, Dai X, Liu H et al (2015) Involvement of PPAR $\gamma$ in emodin-induced HK-2 cell apoptosis. Toxicol in Vitro 29:228-233

Wang F, Zhang D, Mao J et al (2017) Morusin inhibits cell proliferation and tumor growth by downregulating c-Myc in human gastric cancer. Oncotarget 8:57187-57200

Wang Y, Yu M, Xu L et al (2018) Diels-Alder type adducts with potent alpha-glucosidase inhibitory activity from Morus macroura. Phytochem Lett 26:149-153

Wang Q-Q, Gao H, Yuan R, Han S, Li X-X, Tang M, Dong B, Li J-X, Zhao L-C, Feng J, Yang S, Yang C-M (2020) Procyanidin A2 a polyphenolic compound exerts anti-inflammatory and anti-oxidative activity in lipopolysaccharidestimulated RAW264.7 cells. PLOS ONE 15(8). https://doi. org/10.1371/journal.pone.0237017

Watada H, Tamura Y (2017) Impaired insulin clearance as a cause rather than a consequence of insulin resistance. J Diabetes Investig 8:723-725

Wilcox G (2005) Insulin and insulin resistance. Clin Biochem Rev 26:19-39

Wink M (2013) Evolution of secondary metabolites in legumes (Fabaceae). S Afr J Bot 89:164-175

Wu W, Yan R, Yao M et al (2014a) Pharmacokinetics of anthraquinones in rat plasma after oral administration of a rhubarb extract. Biomed Chromatogr 28:564-572

Wu Y, Ding Y, Tanaka Y, Zhang W (2014b) Risk factors contributing to type 2 diabetes and recent advances in the treatment and prevention. Int J Med Sci 11:1185-1200

Wüpper S, Fischer A, Lüersen K et al (2020) High dietary kuding tea extract supplementation induces hepatic xenobiotic-metabolizing enzymes - a 6-week feeding study in mice. Nutrients 12:1-14
Xi J, Chang Q, Chan CK, Meng ZY, Wang GN, Sun JB, Wang YT, Tong HHY, Zheng Y (2009) Formulation development and bioavailability evaluation of a self-nanoemulsified drug delivery system of oleanolic acid. AAPS Pharm Sci Tech 10(1):172-182. https://doi.org/10.1208/s12249009-9190-9

Xia CL, Tang GH, Guo YQ et al (2019) Mulberry Diels-Aldertype adducts from Morus alba as multi-targeted agents for Alzheimer's disease. Phytochemistry 157:82-91

Xu X, Xie H, Wang Y, Wei X (2010) A-type proanthocyanidins from lychee seeds and their antioxidant and antiviral activities. J Agric Food Chem 58(22):11667-11672. https://doi.org/10.1021/jf1033202

Xu HY, Feng XH, Zhao PF et al (2019) Procyanidin A2 penetrates L-02 cells and protects against tert-butyl hydroperoxide-induced oxidative stress by activating Nrf2 through JNK and p38 phosphorylation. J Funct Foods 62:1-9

Yamashita Y, Wang L, Nanba F, Ito C, Toda T, Ashida H, Kanzaki M (2016) Procyanidin promotes translocation of glucose transporter 4 in muscle of mice through activation of insulin and AMPK signaling pathways. PLOS ONE 11(9). https://doi.org/10.1371/journal.pone.0161704

Yang HJ, Youn HS, Seong KM et al (2011) Psoralidin, a dual inhibitor of COX-2 and 5-LOX, regulates ionizing radiation (IR)-induced pulmonary inflammation. Biochem Pharmacol 82:524-534

Yang JB, Tian JY, Dai Z et al (2017) a-glucosidase inhibitors extracted from the roots of Polygonum multiflorum Thunb. Fitoterapia 117:65-70

Yared JA, Tkaczuk KHR (2012) Update on taxane development: New analogs and new formulations. Drug Des Devel Ther 6:371-384

Yeung AWK, Georgieva MG, Atanasov AG, Tzvetkov NT (2019) Monoamine oxidases (MAOs) as privileged molecular targets in neuroscience: research literature analysis. Front Mol Neurosci 12:1-12

Yin Z, Zhang W, Feng F et al (2014) $\alpha$-Glucosidase inhibitors isolated from medicinal plants. Food Sci Hum Wellness $3: 136-174$

Yin M-C (2015) Inhibitory effects and actions of pentacyclic triterpenes upon glycation. BioMedicine 5(3):13. https:// doi.org/10.7603/s40681-015-0013-x

Yin J, Xiang C, Song X (2016) Nanoencapsulation of psoralidin via chitosan and Eudragit S100 for enhancement of oral bioavailability. Int J Pharm 510:203-209

Yuan Y, Zhang H, Sun F et al (2015) Biopharmaceutical and pharmacokinetic characterization of asiatic acid in Centella asiatica as determined by a sensitive and robust HPLC-MS method. J Ethnopharmacol 163:31-38

Zhai Y, Li Y, Wang Y et al (2017) Psoralidin, a prenylated coumestan, as a novel anti-osteoporosis candidate to enhance bone formation of osteoblasts and decrease bone resorption of osteoclasts. Eur J Pharmacol 801:62-71

Zhai Y, Wang Q, Li Y et al (2018) The higher osteoprotective activity of psoralidin in vivo than coumestrol is attributed by its presence of an isopentenyl group and through activated PI3K/Akt axis. Biomed Pharmacother 102:1015-1024

Zhang L, Zhu Mf, Tu ZC et al (2017) a-Glucosidase inhibition, anti-glycation and antioxidant activities of Liquidambar 
formosana Hance leaf, and identification of phytochemical profile. S Afr J Bot 113:239-247

Zhang X, Li G, Wu D et al (2019) Emerging strategies for the activity assay and inhibitor screening of alpha-glucosidase. Food Funct 11:66-82

Zhao Y, Wang L, Miao H et al (2011) LC method for the determination of rhaponticin in rat plasma, faeces and urine for application to pharmacokinetic studies. Chromatographia 73:599-603

Zhao Y-Y, Su Q, Cheng X-L et al (2012) Pharmacokinetics, bioavailability and metabolism of rhaponticin in rat plasma by UHPLC-Q-TOF/MS and UHPLC-DAD-MSn. Bioanalysis $4: 713-723$
Zhao F, Tian H, Chinnathambi A et al (2020) Neuroprotective effect of rhaponticin against Parkinson disease: insights from in vitro BV-2 model and in vivo MPTP-induced mice model. J Biochem Mol Toxicol 10:1-9

Zhuang M, Jiang H, Suzuki Y et al (2009) Procyanidins and butanol extract of Cinnamomi Cortex inhibit SARS-CoV infection. Antivir Res 82:73-81

Publisher's Note Springer Nature remains neutral with regard to jurisdictional claims in published maps and institutional affiliations. 